Article

\title{
An Assessment and Spatial Modelling of Agricultural Land Abandonment in Spain (2015-2030)
}

\author{
Carolina Perpiña Castillo ${ }^{1, *(1)}$, Eloína Coll Aliaga ${ }^{2}$, Carlo Lavalle $^{1}$ and \\ José Carlos Martínez Llario ${ }^{2}$ \\ 1 European Commission, Joint Research Centre (JRC), 21027 Ispra, Italy; carlo.lavalle@ec.europa.eu \\ 2 Department of Cartographic Engineering, Geodesy and Photogrammetry, Universitat Politècnica de València, \\ Camino de Vera, s/n, 46022 Valencia, Spain; ecoll@cgf.upv.es (E.C.A.); jomarlla@cgf.upv.es (J.C.M.L.) \\ * Correspondence: carolina.perpina@ec.europa.eu or capercas@topo.upv.es
}

Received: 14 November 2019; Accepted: 11 December 2019; Published: 11 January 2020

\begin{abstract}
This article presents a study based on the outputs from the LUISA Territorial modelling platform (Joint Research Centre of the European Commission) focused on regional and local future projections of land abandonment between 2015 and 2030. Spain is taken as representative of one of the countries highly affected by agricultural land abandonment in the European Union. The most relevant factors driving land abandonment (biophysical, agroeconomics, farm structure and demographic) are described and mapped. Results from the analysis reveal that the Galicia region, northern Spain (Asturias, Cantabria, Gipuzkoa, Bizkaia), north-eastern Spain (Aragón region), central Pyrenees/Ebro basin (Huesca, Navarra, Lleida) and south-eastern Spain (Murcia, Almería, Alicante, Málaga) are expected to undergo important abandonment processes. The study also concludes that land abandonment within mountainous, high nature value farmland and Natura 2000 areas is lower compared to the outside area without conservation and protection measures.
\end{abstract}

Keywords: agricultural land abandonment; land-use modelling; Spain; risk map; policy layers; LUISA platform

\section{Introduction}

Agricultural land abandonment is the largest land-use change process in Europe. The causes have been changing over time in the most developed European countries. While in the 19th century, the industrialization process and the end of World War II were the main causes of land abandonment [1], nowadays, EU agricultural policies, market pressures, depopulation, rapid urbanization or environmental factors have highly contributed to exacerbating the process [2]. In particular, land abandonment in European mountains and remote areas has been widely analysed [3-8] owing mainly to the depopulation of some areas ("rural exodus"), low incomes and productivity of farm activities because of new opportunities off-farm and unfavourable natural constraints. However, the land abandonment problem is widely spread beyond mountainous and marginal areas, and the situation varies from place to place due to economic, social and demographic situations, natural and environmental conditions, historical and regional context and local preferences $[9,10]$.

A broad number of studies [2,6,11-15] identify a set of drivers that are commonly referred to as the following categories: (1) The environmental factors that constrain agricultural production (soil quality, slope, elevation, fertility, soil depth, seasonal climate, etc.); (2) the socioeconomic situation that expresses the lack of (farm) economic and demographic viability and stability (farm size, supply of labour, age of farmers, productivity levels, policy schemes, low land market mobility, farm investment and industrialisation, trades, etc.); (3) the regional context that measures the level of accessibility (to infrastructure, services and market), distance variables (to major settlements, 
to forest patches, to remote areas), EU agricultural policy instruments, rapid urbanization processes, population distribution and rural-urban migration; and (4) the mismanagement of soil and water resources leading to land degradation, soil erosion, overexploitation of groundwater resources causing water scarcity and salinization of croplands.

Land abandonment affects millions of hectares in Europe with its associated implications [16]. The combination of various mentioned factors produces very diverse impacts that alter biogeochemical and hydrological cycles, soil properties, an increase of forest fires, erosion, landslides, landscape transformation as well as affects socio-economic aspects [17-20]. However, revegetation is one of the positive options once land abandonment occurs and, if it naturally evolves, moves from herbaceous plants and shrubs to young forest. A successful recovery entails an improvement in soil properties and nutrients, land stabilization, among others, with the inherent increase of organic matter content [21]. Beyond the environmental impacts, abandonment affects not only the abandoned area itself but also its local population and the whole society in terms of production of goods (e.g., foods, feed, fibre and biomass production) as well as other services provided by the multifunctionality of the agricultural land $[22,23]$. In this context, food security can be one of the major challenges for the future of the EU, aiming at keeping its agricultural production potential and considering the implications on important aspects of the rural economy [13]. For many regions in Europe, the agricultural sector still plays a significant economic role [24] and its eventual decline due to massive abandonment, among other factors, might cause a loss of jobs in the agricultural and related sectors, out-migration of young people and a decline in the management of agroecosystems $[17,23]$. The decrease in agricultural land influences agricultural outputs and management practices. Changes in management practices such as agricultural intensification and specialization lead to high productivity in more fertile areas, while producing marginalisation and abandonment in others [25]. Many farming regions, especially in central and eastern parts of Europe, have been also affected by economic and political transformation (collapse of the former URSS, Common Agricultural Policy (CAP) subsidies system or market globalization), the loss of export markets, the reduction in domestic support, the transition to free-market economies, etc. causing the reduction of agricultural viability, stability and profitability triggering massive land abandonment processes $[22,25,26]$.

In particular, Spain is one of the countries in which more studies have been conducted to measure and assess the impacts of land abandonment. Despite the scope of many of these studies being on a local scale, they reflect the evolution of Spanish agriculture and the correlation with the climate, soil and terrain conditions $[27,28]$. However, many changes occurred during the last century in the agricultural production system of Spain, dealing with the real problem of land abandonment and its negative environmental, biological, hydrological, geomorphological, socioeconomic and cultural consequences [2]. Hydraulic infrastructure began to be an important policy after the 1960s in order to increase productivity, diversification and intensification of cropland, especially in the semi-arid area of Spain resulting in many cases in overexploitation of water resources [11]. After the implementation of the Common Agricultural Policy (CAP) in 1986 and its posterior reform in 1992, Spain underwent an inflexion point where the agricultural outputs declined, and the loss of utilised agricultural area (UAA) constantly increased [27]. The CAP started to subsidize some crops to the detriment of others, producing a reallocation of agricultural systems from the humid north to the semi-arid regions [11]. This situation led to the need of building new terrace structures in marginal and steep-slopes in order to host the expansion of vineyards and other orchard trees at the expense of forest, cereals fields and fodder crops [29]. The CAP has also influenced other aspects with the application of the set-aside policy that potentially increases the risk of erosion and abandonment leaving the land uncultivated. Besides, by the 1980s, technological and industrial developments, demographic dynamics with important depopulation rates (especially in the most mountainous and rural areas) and the influence of international markets (demand and price) had an impact on the agricultural Spanish system.

The objective of this paper, therefore, is to present an assessment of future territorial patterns and the main drivers of land abandonment based on the outputs from the LUISA Territorial modelling 
platform under the 2017 Reference Scenario. The emphasis is to statistically and spatially analyse the extent and the location of agricultural land abandonment by 2030 at the national, regional and local levels in Spain. By agricultural land abandonment, we refer to land that was previously used for crop or pasture but has no more farming functions, which basically means a total cessation of agricultural activities. This article takes on board the most important novelties that were integrated in the spatial-explicit framework aiming at modelling future agricultural abandonment, in particular: (1) the dynamic character through the simulation period (2015-2030), (2) the spatial resolution of the abandonment and the EU risk map (100 m grid cell) and (3) future projections of the agricultural land abandonment while competing with other land uses (urban, industry, forest, etc.).

\section{Materials and Methods}

LUISA modelling platform is used as the main tool to project likely areas of future agricultural abandonment, due to its ability to simulate spatial patterns and trends of different land functions. In particular, the more relevant components and factors driving land abandonment in the current modelling exercise are briefly described in this section. A complementary evaluation of abandonment land on areas with natural or other specific constraints (Natura 2000 payments to agriculture and agri-environment measures of the Pillar II of the CAP to prevent land abandonment) is also conducted.

\subsection{An Introduction of LUISA Territorial Modelling Platform}

LUISA is a pan-European modelling platform that provides alternative scenarios of territorial development in order to understand the impacts of certain EU policies in an integrated and spatiallyexplicit framework. It also intrinsically takes on boards existing European policies and legislation e.g., Common Agricultural Policy, Renewable energies, Trans-European Transport Network, EU Biodiversity strategies or protection of Natura 2000 areas.

LUISA coherently links specialised macro-economic, demographic and geospatial models with other thematic spatial/statics databases in order to simulate the local allocation of land functions. Sectoral claims are allocated over the land according to their specific and historical location, land suitability, restrictions of spatial policies, transition rules, conversion costs, neighbourhood effects, etc. Future land projections, in hectares of land, are derived from a set of external models that govern the starting stage of the simulation. Demographic projections are based on EUROPOP 2013 [30] for the period 2015-2060 at the national level. CAPRI model [31] provides future agricultural land demands. Economic projections (GDP and GVA) are derived from the GEM-E3 [32] and RHOMOLO [33] models, while energy projections depend on the JRC-EU-TIMES model [34]. Future forest land demands are computed based on afforestation or deforestation rates at the national level according to UNFCCC (United Nations Framework Convention on Climate Change) reports [35].

LUISA model spatially relies on CORINE land cover (CLC2012) datasets owing to its complete and consistent information on land use/cover across Europe. However, due to the spatial and thematic limitations of the CLC2012 dataset, a more enriched version called LUISA Base map 2012 is used in the base year of the simulation, 2012, for projecting the land use/function spatial classes onwards [36,37]. Land-use classes from the LUISA base map are grouped, for modelling purposes, in a smaller number of relevant categories in the last Reference scenario 2017 (see next section).

The main direct outputs of LUISA are simulated land use/cover maps, accessibility and population distribution with a spatial resolution of $100 \mathrm{~m}$, a temporal resolution of 5 years (from 2015 to 2050) and covering the EU28. These outputs are modelled using discrete land-use modelling methods that assume that various land uses compete with each other for the best locations. A discrete choice model assigns probabilities for the different alternatives according to the utility of those alternatives in relation to the total utility of all alternatives [38]. The followed approach optimizes the overall utility of the land-use distribution, given the amount of available land in a region and the regional land demands as 
constraints [39]. A logit-type model is applied, in a spatially-explicit manner, where the probability of choosing among mutually exclusive land-based activities is computed as shown in Equation (1):

$$
P_{r, i}=\frac{e^{\beta * U_{r, i}}}{\sum_{k=1}^{n} e^{\beta * U_{r, k}}}
$$

where $P_{r, i}$ is the probability of alternative $i$ being chosen in gridcell $r, U_{r, i}$ is the utility of alternative $i$ in gridcell $r$ (i.e., the NPV of that activity in that particular location), $U_{k}$ is the utility of alternative $k, n$ is a finite number of mutually exclusive alternatives for land-based activities and $\beta$ is a parameter to adjust the model sensitivity (typically 1 as default value).

The utility of the modelled land use/function is defined economically through their net present value (NPV) at a specific location [40]. Land-based activities require investments with a long-term time horizon and, in a spatially-explicit way, is formulated as Equation (2) shows:

$$
N P V_{r}=-I+\sum_{t=y}^{n} \frac{R_{r, t}-C_{t}}{(1+d)^{t-y}}
$$

where $I$ are the initial investment costs (in $€ /$ ha, e.g., land clearing/demolition costs, building costs, acquiring agricultural machinery), $R_{r, t}$ are the annual gross revenues for raster cell $r$ in year $t$ (in $€ /$ ha, obtained from e.g., rental income, revenues from selling crops, subsidies), $C t$ are annual costs (in $€ /$ ha, e.g., maintenance costs, field operations in agriculture), $n$ is the investment time-horizon (in years) and $d$ is the discount rate. Gross revenues $\left(R_{r},\right)$ are highly dependent on local specific conditions such as climate, landscape or accessibility. Therefore, local suitability, or more precisely the percentage of maximum revenue to be obtained at a specific raster cell is estimated through country-specific binomial logistic regression analyses (more information on data and the applied method can be found in $[35,36]$ ).

From the primary LUISA outputs together with external data and models, many other land functions and thematic indicators are subsequently computed according to the sector under assessment. A land function can, for example, be societal (e.g., provision of housing, leisure and recreation), economic (e.g., provision of employment, investments, energy, food, fuels, consumer goods, etc.) or environmental (e.g., related to hydrology or emissions). More information about LUISA applications and indicators, population distribution maps, key components, parametrization, data sources, modular structure and methods can be found in [35,36,41-45]. The data and indicators produced by LUISA are publicly accessible by a web platform from the Urban Data Platform [46] and The Territorial Dashboard [47].

\subsection{Modelling Agricultural Land Abandonment in LUISA Platform}

Agricultural land abandonment is one of the classes simulated in the LUISA model that can be classified in three different categories: abandoned arable land, abandoned permanent crops and abandoned livestock grazing. In terms of modelling, abandonment is a phenomenon that depends on the results of the land-use utility optimization process integrating endogenously a set of components. Firstly, the model needs to be feed by the agricultural land demands projected up to 2030 derived from the 2016 CAPRI baseline regional projections while, at the same time, competition among other land use/function (urban, industry, forest, etc.) is produced (Section 2.2.1). Secondly, abandonment expectations for the three mentioned categories of abandoned agricultural are dynamically quantified into ranges of shares of abandoned land (maximum and minimum values) per each member state according to the past trends observed in CLC between 2000 and 2012. Thirdly, a dynamic composite indicator map assesses the potential risk of farmland abandonment by the spatial integration of biophysical, agroeconomic, demographic and geographic driving factors (Sections 2.2.2-2.2.4). This aggregation of factor sets is implemented by using a weighted linear addition method, where biophysical factors are assigned the highest weights (0.4) while agroeconomic and demographic factors are slightly lower ( 0.3 , respectively) summing up 1 all together. This follows the assumption that abandonment processes are most likely 
triggered initially in low-yield remote mountainous regions, and in regions with unfavourable soil and climate conditions for agriculture.

The selection of the main factors for modelling the risk map of agricultural land abandonment are based on recent scientific literature $[6,10,12-16]$ adapted by the authors for the purpose of this study. Biophysical conditions, agriculture's socio-economic factors, farm structure characteristics, areas with low population density and remoteness are considered the main features. Table 1 briefly describes each factor and includes the data source (more information can be found in [41]). In the LUISA model, the geographic projection European Terrestrial Reference System 89, Lambert Azimuthal Equal Area projection (ETRS89 LAEA) is commonly used. National and regional boundaries correspond to the version NUTS 2013 layer of administrative or statistical available from the Geographic Information System of the Commission (GISCO) [48]. Some spatial data are aggregated to administrative units for better visual and numerical interpretation.

Table 1. Description of the components and factors for modelling agricultural land abandonment.

\begin{tabular}{|c|c|c|}
\hline Factor & Description & Source \\
\hline $\begin{array}{l}\text { Land use/cover } \\
\text { maps }\end{array}$ & $\begin{array}{l}\text { Primary outputs of the simulation whose land-use } \\
\text { classes refer to: residential, industry, agricultural } \\
\text { systems, agricultural land abandonment, forest and } \\
\text { naturally vegetated areas. Spatial and temporal } \\
\text { resolution: } 100 \mathrm{~m} \text {; from } 2012 \text { to } 2030 .\end{array}$ & LUISA platform $[49,50]$ \\
\hline \multicolumn{3}{|c|}{ Biophysical } \\
\hline $\begin{array}{l}\text { Length of growing } \\
\text { period }\end{array}$ & $\begin{array}{l}\text { Number of days when the average daily temperature is } \\
\text { above a certain temperature threshold. }\end{array}$ & {$[51]$} \\
\hline Soil Organic matter & Topsoil $(0-30 \mathrm{~cm})$ organic matter content. & {$[52,53]$} \\
\hline Soil texture & $\begin{array}{l}\text { Soil texture with less than } 18 \% \text { clay, more than } 65 \% \text { sand, } \\
\text { or which have stones, boulders or rock at the surface are } \\
\text { considered not favourable for crop growth. }\end{array}$ & {$[54]$} \\
\hline Root depth & $\begin{array}{l}\text { To ensure maximum root development due to the } \\
\text { presence of specifics horizon that cannot be penetrated } \\
\text { by the roots. }\end{array}$ & {$[54]$} \\
\hline Soil pH & $\begin{array}{l}\text { Spatial layer of topsoil } \mathrm{pH} \text { which represents the } \mathrm{pH} \\
\text { given for the dominant soil; extreme values are } \\
\text { considered not favourable for crop growth. }\end{array}$ & {$[53,55]$} \\
\hline $\begin{array}{l}\text { Salinity and } \\
\text { sodicity }\end{array}$ & $\begin{array}{l}\text { Medium or high salinity concentration areas are } \\
\text { proposed as unfavourable agricultural conditions. Soil } \\
\text { sodicity is a land characteristic for which the proportion } \\
\text { of absorbed sodium in the soil clay fraction is too high } \\
\text { for plants to perform or survive. }\end{array}$ & [54] \\
\hline Precipitation & $\begin{array}{l}\text { Total mean annual precipitation calculated as the sum of } \\
\text { the mean monthly precipitation. }\end{array}$ & [55] \\
\hline Soil drainage & $\begin{array}{l}\text { It refers to the maintenance of the gaseous phase in soil } \\
\text { pores by the removal of water. Imperfect, poor and very } \\
\text { poorly drained soils are considered not favourable for } \\
\text { crop growth. }\end{array}$ & {$[54]$} \\
\hline Slope & $\begin{array}{l}\text { Flat areas or with a slope }<8 \% \text { are the most appropriated } \\
\text { for crop growth. Slopes in excess of } 16 \% \text { will provide } \\
\text { difficulty for harvesting machinery. }\end{array}$ & {$[56]$} \\
\hline \multicolumn{3}{|c|}{ Agroeconomic and farm structure } \\
\hline Age of farmers & $\begin{array}{l}\text { The number of farmers }>65 \text {-year-old over the total } \\
\text { number of farmers. It is assumed that abandonment is } \\
\text { more likely to occur when the farmer is close to the } \\
\text { retirement age. NUTS3 level. }\end{array}$ & $\begin{array}{l}\text { Data: Holders above } \\
\text { 65_ef_r_farm2007.xls [57] }\end{array}$ \\
\hline $\begin{array}{l}\text { Farmer } \\
\text { qualification }\end{array}$ & $\begin{array}{l}\text { Share of farmers with practical experience with regard to } \\
\text { the total number of trained farmers. Farmer with high } \\
\text { qualification invest more in human capital, etc., thus } \\
\text { preventing farmland abandonment. NUTS0 level. }\end{array}$ & $\begin{array}{l}\text { Data: Total_ef_mptrainman.xls, } \\
\text { Practicalexperience_ef_mptrainman.xls } \\
\text { [57] }\end{array}$ \\
\hline
\end{tabular}


Table 1. Cont.

\begin{tabular}{|c|c|c|}
\hline Farm size & $\begin{array}{l}\text { Share of farms (UAA) under } 50 \% \text { of the average size } \\
\text { region (NUTS3 level). In this way, large farms compared } \\
\text { to small (fragmented) farms are usually more } \\
\text { competitive and viable from an economic point of view. }\end{array}$ & $\begin{array}{l}\text { Data: Size and type_ef_r_farm-3.xls } \\
\text { [57] }\end{array}$ \\
\hline Rent paid & $\begin{array}{l}\text { Rent paid is used as a proxy of the strength or weakness } \\
\text { of the land market. It is assuming that high rental prices } \\
\text { lead to high demand for agricultural land and therefore, } \\
\text { a low risk of abandonment. Units: Euro. }\end{array}$ & {$[58]$} \\
\hline Rented UAA & $\begin{array}{l}\text { Share of the rented UAA over the total UAA. It is } \\
\text { assumed that the lower the rented UAA, the higher the } \\
\text { abandonment risk. Units: ha }\end{array}$ & [58] \\
\hline Farm income & $\begin{array}{l}\text { This variable is used as a proxy of economic performance } \\
\text { compared to the gross domestic product (GDP) per } \\
\text { capita. National GDP is a proxy of national income. It is } \\
\text { assumed that the lower the income, the higher the } \\
\text { abandonment risk. Units: Euro. }\end{array}$ & Data: nama_gdp_c.xls $[57,58]$ \\
\hline Farm investment & $\begin{array}{l}\text { This variable can be interpreted as a proxy of improving } \\
\text { (new machinery, new technics) and continuing farm } \\
\text { activities, hence reducing the risk of abandonment. } \\
\text { Units: Euro. }\end{array}$ & [58] \\
\hline $\begin{array}{l}\text { Farm scheme } \\
\text { (subsidies) }\end{array}$ & $\begin{array}{l}\text { The indicator is computed by using the variable "Farm } \\
\text { subsidies" normalized by the UAA sample area. It is } \\
\text { assumed that the lower the subsidies, the higher the } \\
\text { abandonment risk. Units: Euro. }\end{array}$ & [58] \\
\hline \multicolumn{3}{|c|}{ Demographic and regional context } \\
\hline $\begin{array}{l}\text { Low population } \\
\text { density }\end{array}$ & $\begin{array}{l}\text { Population density below } 50 \text { inhabitants } / \mathrm{km}^{2} \text { is } \\
\text { considered very low populated areas. The modelling } \\
\text { mechanism counts for each cell the allocated residents } \\
\text { within a surrounding kernel with an area of } \\
\text { (approximately) } 1 \mathrm{~km}^{2} \text {; then, it is possible to identify the } \\
\text { cells with less than } 50 \text { inhabitants inside the surrounding } \\
\text { kernel. }\end{array}$ & $\begin{array}{l}\text { LUISA population density map based } \\
\text { on EUROPOP2013 [30] }\end{array}$ \\
\hline Remote areas & $\begin{array}{l}\text { Remote areas are represented as a dynamic map of } \\
\text { travelling time to the nearest town. Thus, remote areas } \\
\text { are identified as those that are further than } 60 \text { min away } \\
\text { from towns. }\end{array}$ & {$[13,14,59]$} \\
\hline
\end{tabular}

\subsubsection{Land-Use Map Projections: Agricultural Land and Land-Use Competition}

Land-use maps are one of the primary outputs after the simulation (Figure 1) where 19 classes are modelled, and 5 classes remain static. Agricultural land is represented by production systems, namely: arable land, mixed-crop livestock, grazing livestock, permanent crops (vineyards, olives trees and fruit trees), rice and bioenergy crops. Agricultural land demand projections are derived from CAPRI agroeconomic model using the CAPRI 2016 Baseline projections up to 2030. CAPRI is a partial equilibrium model that simulates market dynamics of agricultural commodities for impact assessment of the Common Agricultural Policy [31].

The projected land requirements, at regional (NUTS1/NUTS2) level for all member states on land area, are used as an input in the LUISA platform. Figure 2 depicts the shares and the percentage of changes in the total agricultural land through the simulation period (2015-2030) at NUTS3 level, showing the regions where there is expected agricultural losses. Thus, projections of land abandonment will rely on the growth or decline of agricultural land trends, competition among land uses for the same piece of land and the potential risk of abandonment. 


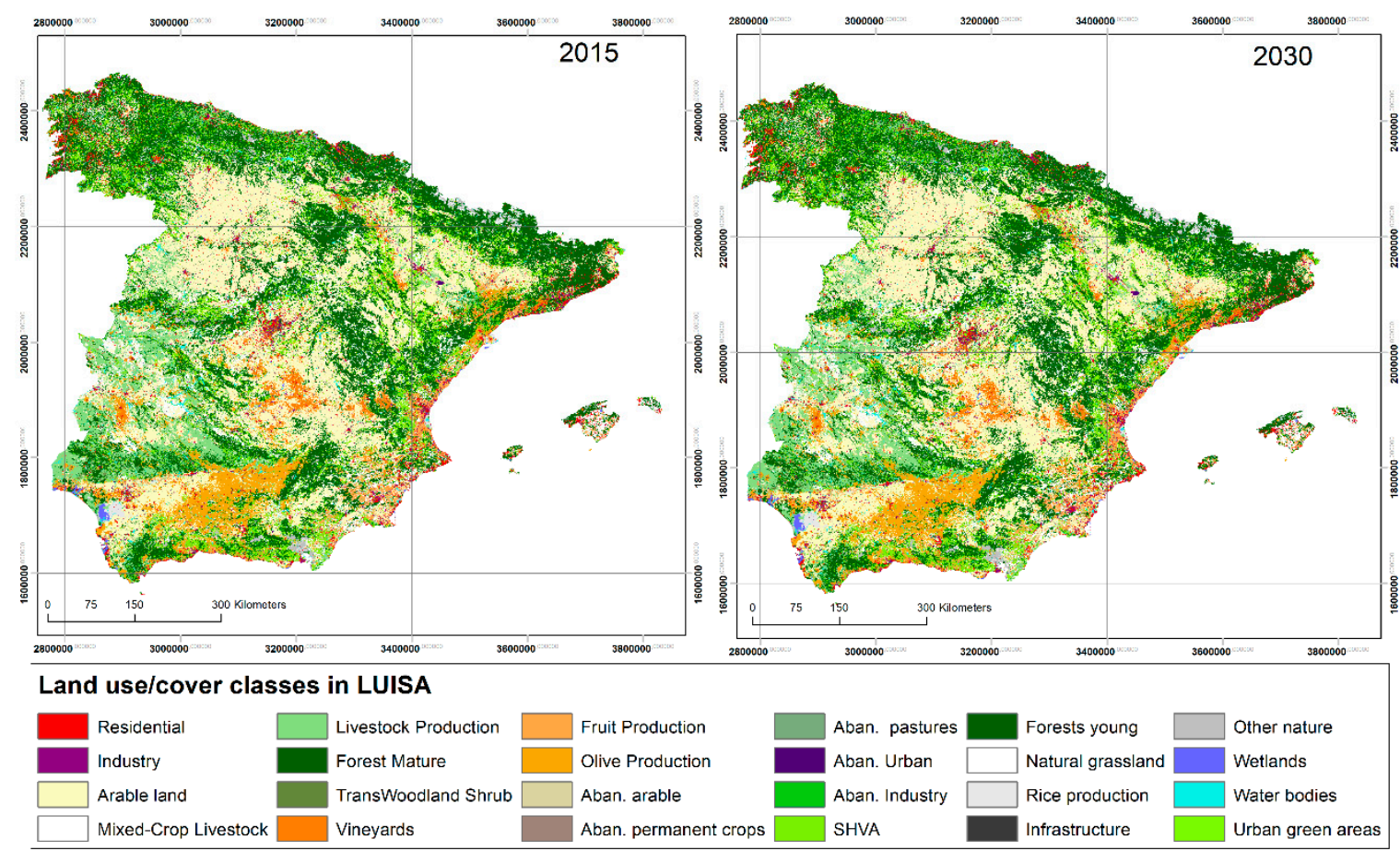

Figure 1. Classification of the modelled land use/cover classes in LUISA as to residential, industrial, agriculture, abandonment, forest and natural areas.

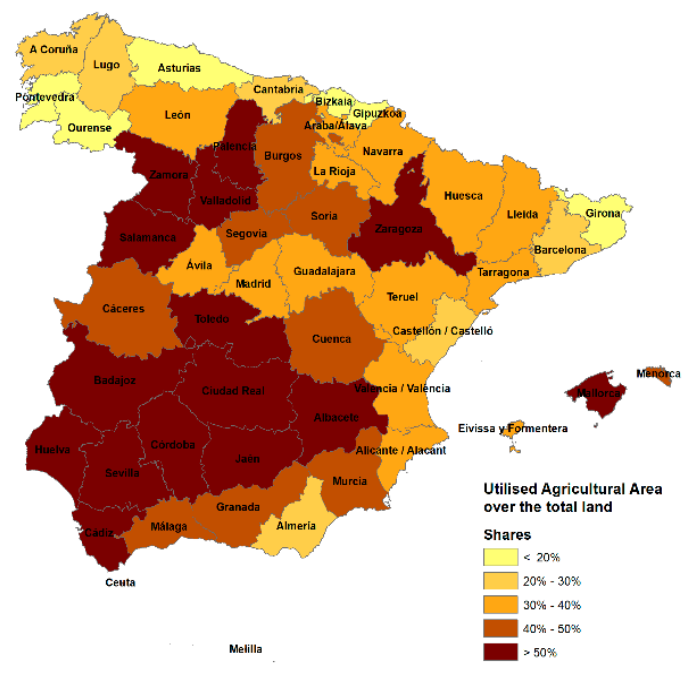

(a)

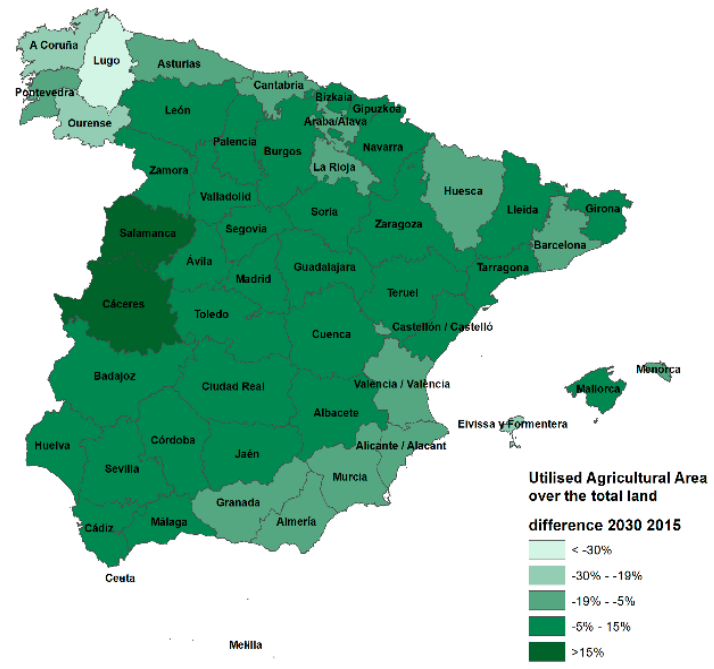

(b)

Figure 2. (a) Shares of UAA with regard to the total regional land surface in 2015; (b) Percentage of change of UAA with regard to the total regional land surface between 2015 and 2030. 


\subsubsection{Biophysical Limitations for Generic Agricultural activities}

Soil, terrain and climate conditions are included as biophysical determinants to reflect natural land suitability. The main purpose is to identify the areas highly affected by severely limiting natural constraints for generic agricultural activity. Those areas, therefore, will be considered as prone to undergo an agricultural abandonment process. According to data availability and spatial coverage, 11 factors were selected based on recent literature $[6,10,12,14,60]$ and the directive 75/268/ECC [61,62]. In particular, length of the growing period, organic matter, soil drainage, precipitation, soil $\mathrm{pH}$, root depth, soil texture, slope, salinity and sodicity are included in the analysis. Figure 3 shows a composite indicator where one or more of those factors are spatially overlapped, thus, producing negative synergies that exacerbate the potential abandonment.

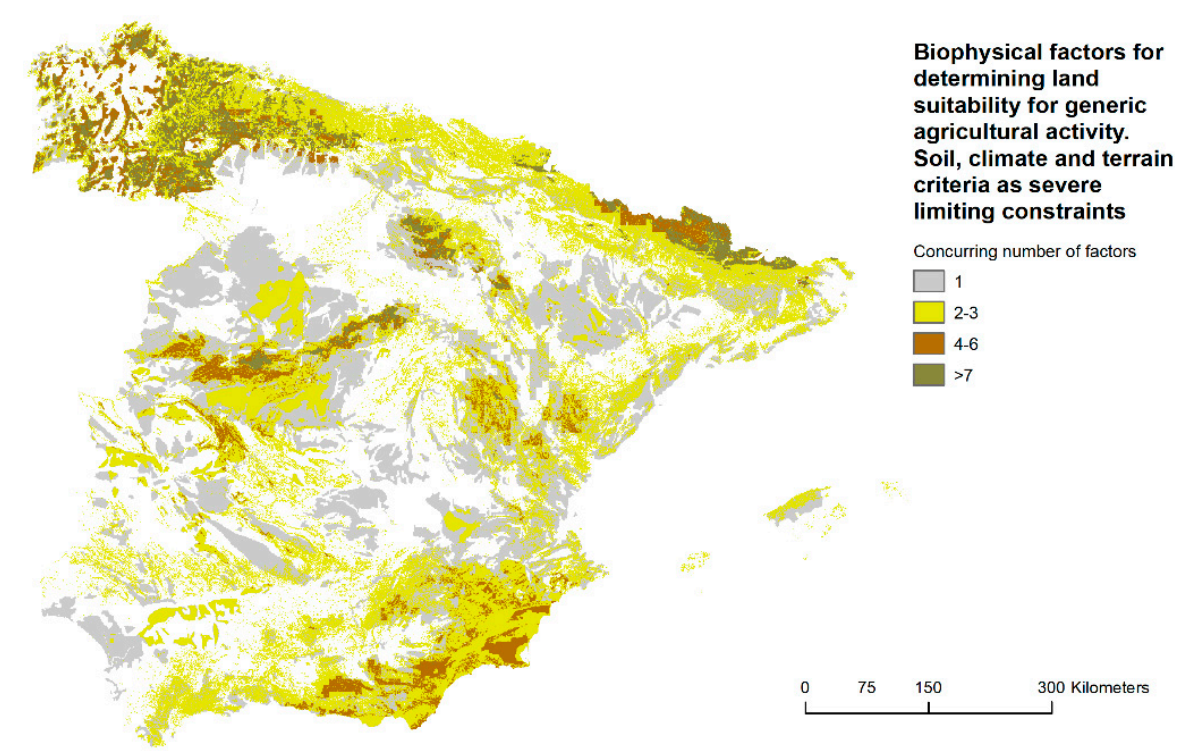

Figure 3. The concurrence of biophysical factors for determining land suitability for generic agricultural activity.

\subsubsection{Agroeconomics and Farm Structural Factors}

Agricultural economy and farm structure information are used to reflect the stability, viability and performance for preventing farmland abandonment at the regional level. This information is mainly gathered from the Farm Accountancy Data Network (FADN) and DG EUROSTAT- Farm Structure Survey (FSS). In particular, three variables are gathered from the FSS: age of farmers, farmer qualification and farm size; and five variables are derived from FADN: rent paid, rented utilised agricultural area (UAA), farm income, farm investment and farm scheme (subsidies). Table 1 explains the assumption for preventing agricultural abandonment for each variable as well as the spatial and temporal resolution. All these variables are considered static throughout the simulation period, averaged over the period 2005-2010 after a harmonization process. This process consisted mainly in filling gaps and matching NUTS3 regions between FSS and FADN due to version discrepancies. Normalization process was applied to make comparable the results among regions and summing up all the variables in a final number associated to each NUTS3. The final goal consists of combining and using both data sources together in a complete and consistent manner. Figure 4 shows the individual maps for each factor at NUTS3 level in Spain. 

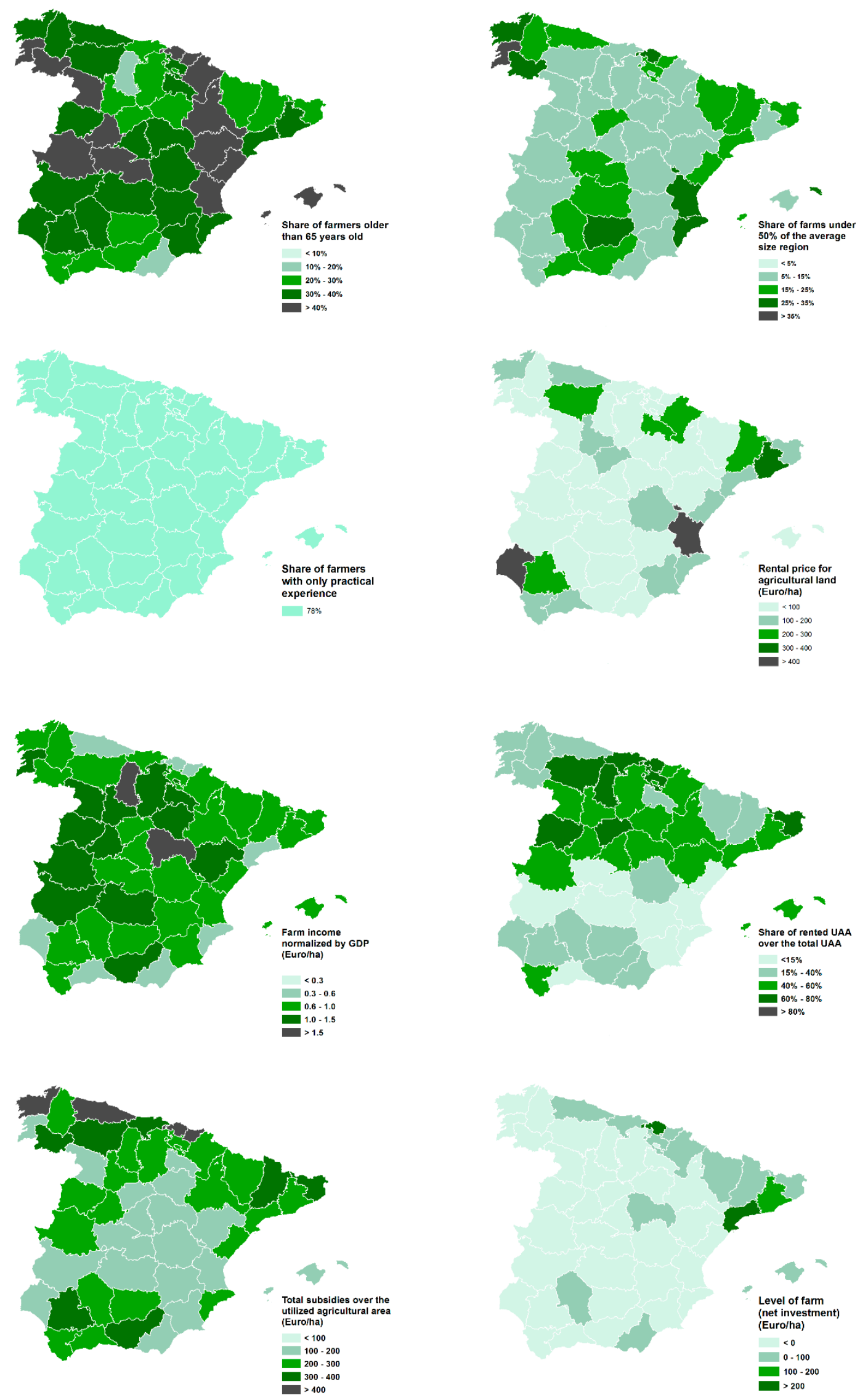

Figure 4. Individual maps of agroeconomic and farm structure factors in Spain. 


\subsubsection{Demographic and Geographic Regional Factors}

Two major drivers are involved in this group, namely: areas with very low population density (below 50 inhabitants $/ \mathrm{km}^{2}$ ) and remoteness (identify as those that are further than 60 min driving away from the nearest town/city) $[13,14,59]$. Cities are considered settlements with a population size greater than 50,000 inhabitants, while for towns correspond between 5000 and 50,000 inhabitants. Both classes share the same population density threshold of 1500 inhabitants per $\mathrm{km}^{2}$ which is considered to be high population density areas. The assumption is that those areas are considered more vulnerable and abandonment is more likely to occur since infrastructures and services are scarce, disperse and inefficient. Remote areas are also prone to be abandoned due to the lack of good accessibility, produced by a poor transport network which impacts negatively on competitiveness and regional development. These two maps (Figure 5) are dynamic throughout the simulation period since they rely on population projections that are changing over time and location. In Spain, practically the whole territory is characterised by very-low population density with the exception of major urban centres and towns.

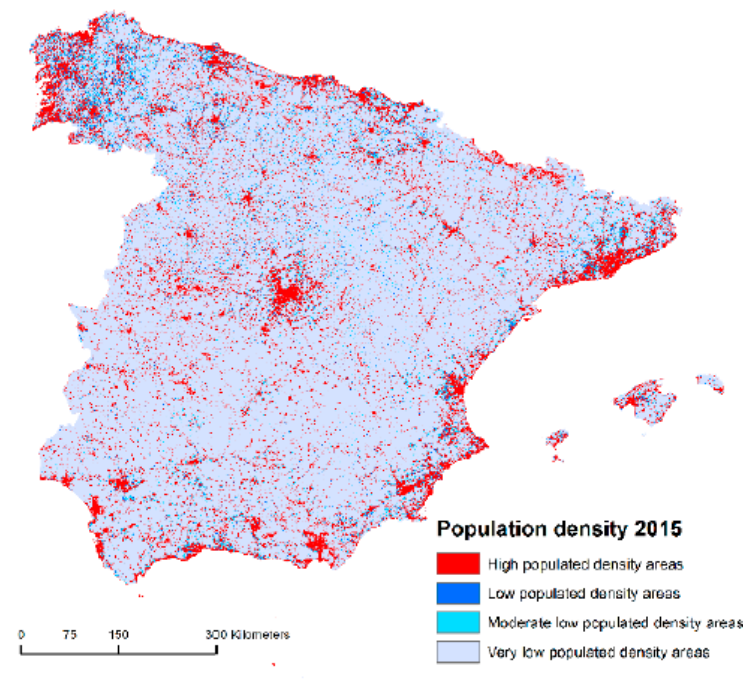

(a)

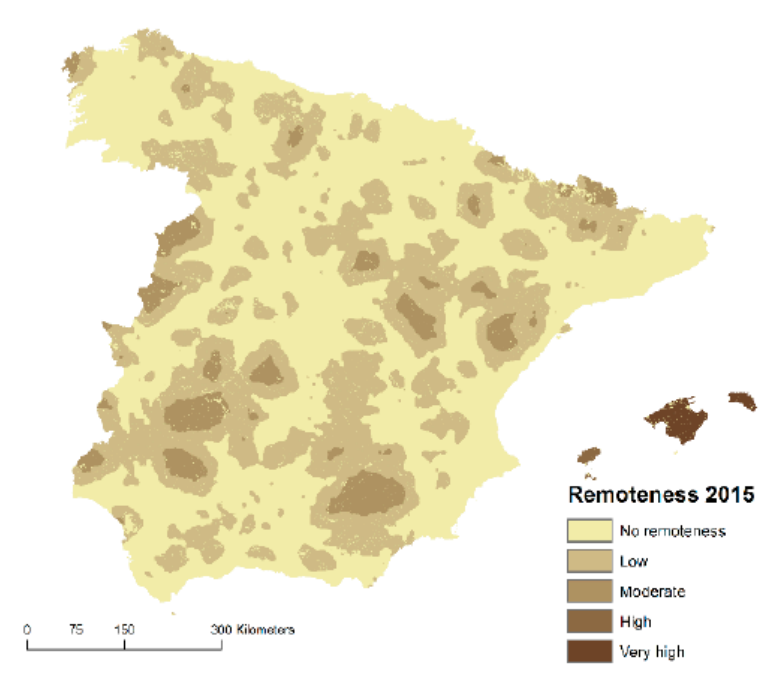

(b)

Figure 5. (a) Population density areas; (b) Remote areas computed endogenously within LUISA.

\subsection{Agricultural Land Abandonment on Mountainous and Natural Areas}

Spain is one of the largest and most biogeographically diverse countries in Europe with an important variety of climatic conditions, together with a rich biodiversity and complex landscape however, at the same time, facing up natural constraints. In this sense, three policy-relevant layers are analysed: totally mountain areas, high nature value farming areas [63] and Natura 2000 sites [64]. In particular, mountain areas have been spatially identified using the less-favoured areas (LFA) classification map, corresponding to the class named "Totally mountain/hill areas" from the Spatial Dataset 2000-2006 based on GISCO Communes (Version 2.4). The assumption of expecting lower abandonment on less-favoured areas, as a consequence of assigning farm payments for maintaining agricultural traditional practices and to promote the conservation of natural habitats and of wild fauna and flora in protected natural areas, is tested. Consequently, a spatial analysis is carried out at a pixel level in order to estimate the area affected by abandonment within each policy-layer in comparison with areas without protection measures. Later on, results are presented as an aggregation at the province level (NUTS3) to keep consistency with the rest of the analysis and for mapping purposes. 


\section{Results}

\subsection{Potential Risk Map of Agricultural Land Abandonment in Spain}

In 2030, roughly 23 million ha of agricultural land are projected to be under different potential risk of land abandonment (Figure 6). The very large majority of that land will, nevertheless, be under low and very low (more than 3/4 of all) risk of abandonment. However, the remaining $1 / 4$, is estimated to be under high $(11 \%)$ and moderate $(10 \%)$ risk of land abandonment, with a residual percentage of about $0.2 \%$ of agricultural land under very high potential risk. Therefore, in absolute figures, these last three categories all together sum up more than 5 million ha, being in severe risk of abandonment by 2030 .

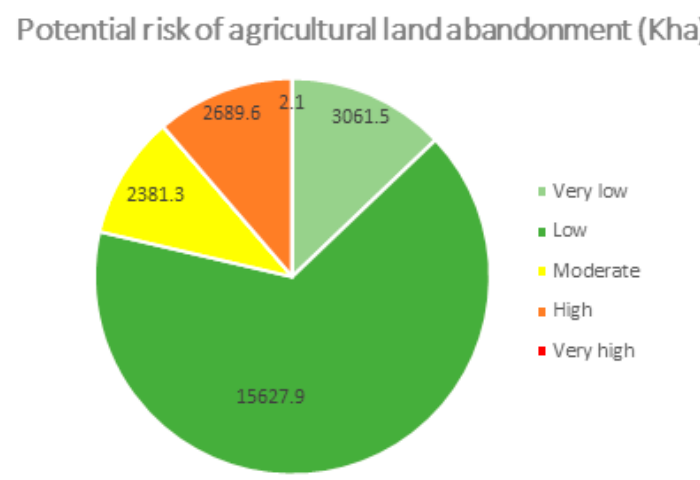

Figure 6. Aggregation of agricultural abandonment by risk categories in Spain.

Spain has one of the most diverse and varied climates in Europe due mainly to its geographical location, its continental mass and the numerous mountain ranges from the north to the south. These biophysical characteristics along with other socio-economic and regional aspects are combined to produce a potential risk of agricultural land abandonment at the grid level for Spain and, later on, aggregated per provinces (Figure 7). Clearly, these two pictures confirm that the risk of land abandonment is not only limited to mountainous areas but also to other vulnerable regions. In the semi-arid south-eastern part of Spain (Murcia, Almería, Granada, Málaga, south of Alicante and Albacete) biophysical factors are the leading group where several of those concur at the same time (Figure 3). In particular, high salinity concentration, low annual precipitation (from 250 to $500 \mathrm{~mm}$ ), fragile and poor soils (heavy clay and coarse texture) prone to degradation and drought, linked to the proximity of the Baetic mountain range dominates south-east Spain [54]. A low population density in the rural mountain area (partially remote) together with an accelerated urbanization and anthropogenic processes in valleys characterises this area (Figure 5). In the north-west Iberian peninsula (mainly the Galicia region) different circumstances leave high rates of abandonment and a risky situation owing to its hilly topography, its peripheral position, predominance small-scale family farms, ownership fragmentation, difficult mechanisation, wildfires risk, intensification of farming and its declaration as a less-favoured area (Directive 75/268/ECC). Important natural constraints to agriculture due to its orography (mainly the Macizo Galaico) along with unfavourable socioeconomic and farm structure factors are also important causes for the increased agricultural abandonment risk in many areas of A Coruña, Lugo and Ourense. Special attention needs to be paid in areas where the presence of moderate, high and very high risk is very pronounced linked to variables such as slope, low soil depth and some patches of poor drainage. Galicia is quite mountainous, which might contribute to isolating rural areas, hampering communications (most notably in the inland) and characterising those areas as remote and lowly populated. Considerable abandonment risk situation is also identified in the Central Ebro Depression partially covering Zaragoza, Huesca, North of Teruel, la Rioja and Navarra. Climatic conditions shift progressively from those influenced by the Atlantic Ocean in the west toward Mediterranean conditions in the east, becoming semi-arid Mediterranean (with drought summer periods) in the central Ebro basin, oceanic in the western Ebro basin and in the Pyrenean parts of the Ebro. Microclimates are 
diverse in this zone defining a broad range in temperature (milder temperatures in the west, with more extreme in the central part) and mean annual precipitation (with $600 \mathrm{~mm}$ on average but ranging from $300 \mathrm{~mm}$ in the Central Ebro to more than $1500 \mathrm{~mm}$ at high altitudes). The orographic and climatic conditions along with low socioeconomic viability and stability, while is considered as remote and low population density area clearly favours processes of abandonment.

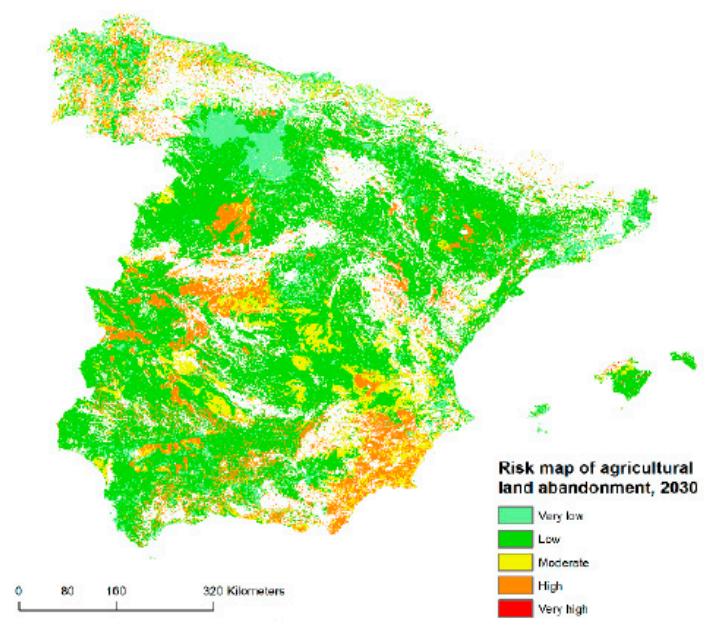

(a)

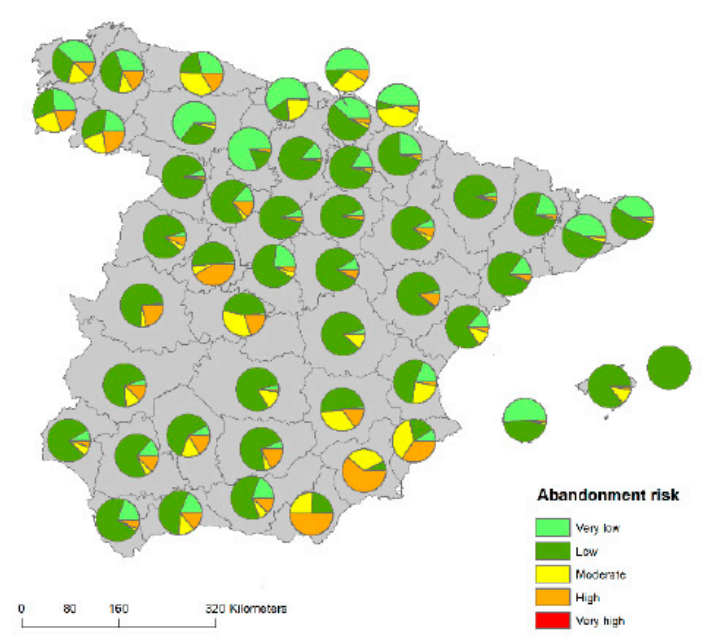

(b)

Figure 7. Map of the potential risk of agricultural land abandonment in 2030 in the EU28. (a) Grid level (100 m resolution); (b) Province level (NUTS 3)

\subsection{Evolution of the Land Abandonment in Spain at Regional Scale, 2015-2030}

In Spain, the total agricultural land abandonment is projected to reach roughly 1.1 million ha which will account for approximately $5 \%$ of the total agricultural land ( 23 million ha) in 2030 . This abandonment share is well above the EU average forecast (3\%) and, actually, Spain is the member state undergoing the worst land abandonment situation [41].

However, looking at a more detailed scale, Spanish regions are not equally affected by land abandonment. Figure 8 presents the relative (as share of total UAA) agricultural land abandonment in 2030 sorted by provinces. Galicia region, in particular, A Coruña, Lugo and Ourense, are likely to face the greatest absolute and relative agricultural land abandonment, being the only three regions in Spain under threat to abandon more than $30 \%$ of the UAA. In terms of absolute figures, we must include to this leading group Zaragoza, Granada, Teruel, Almería, Murcia, Valencia, Huesca and Albacete with the largest agricultural land abandonment areas in Spain (above the Spanish average of $30 \mathrm{Kha}$ ), and altogether responsible for $50 \%$ of abandonment. Moreover, most of those regions (except Zaragoza and Albacete) are not the ones with the large regional agricultural productive land that, actually, can exacerbate the situation. Conversely, in the last part of the ranking, we can find Baleares islands, Sevilla, Huelva and Girona, while in relative terms, many regions in Castilla-La Mancha and Castilla y León are foreseen to be less affected by abandonment (below 5\%).

For a better interpretation and visualization, Figure 9 presents the map of projected abandoned agricultural land in 2030 per province. Based on the highest abandonment expectations, it is possible to distinguish two clear clusters in Spain: north-western and north, and south-eastern Spain. It confirms that Galicia is expected to face the biggest challenges in Spain, especially where Lugo will be affected the most, with almost 80 thousand ha of abandoned land, followed by A Coruña and Ourense. Other regions in south-eastern Spain, which are likely to face significant land abandonment, are Valencia, Albacete, Murcia, Almería and Granada. The last cluster corresponds to a complete region, namely Aragón (Huesca, Zaragoza and Teruel). In northern Spain, due mainly to the mountainous ranges, substantial agricultural abandonment is projected for Asturias, Cantabria, Gipuzkoa and Bizkaia (in relative terms). 
It is also worth noting that regions in central Spain (except Ávila and Madrid) are expected to undergo less abandonment, where the trend is not spread to the regions of the surrounding (outer) belt.

SHARE OF AGRICULTURAL LAND ABANDONMENT OVER THE TOTAL UAA, 2030

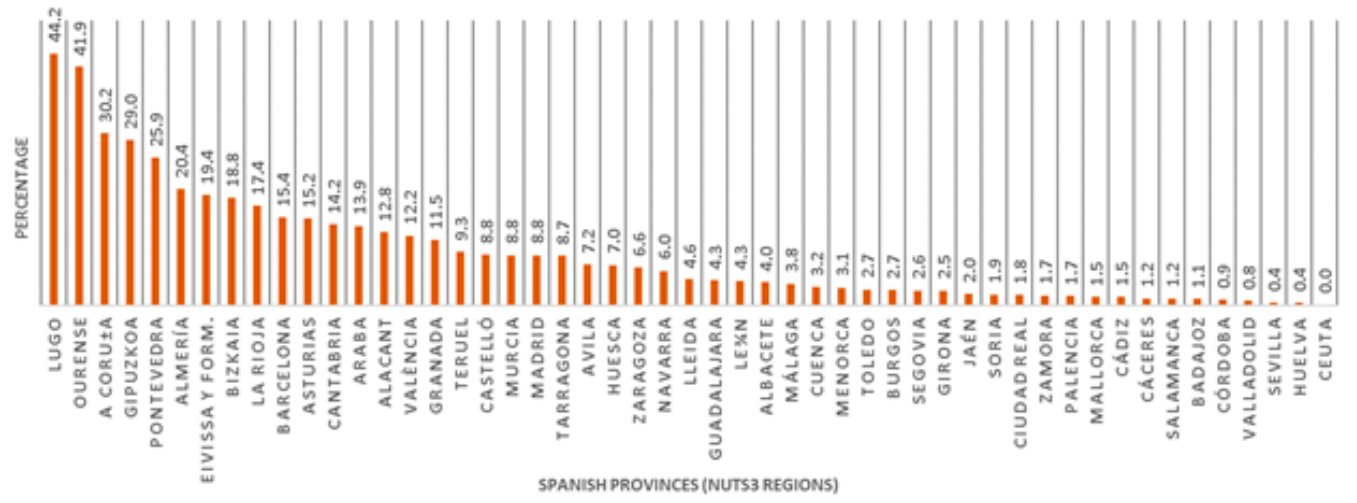

Figure 8. Agricultural land abandonment (shares) per province (NUTS3) in Spain in 2030.

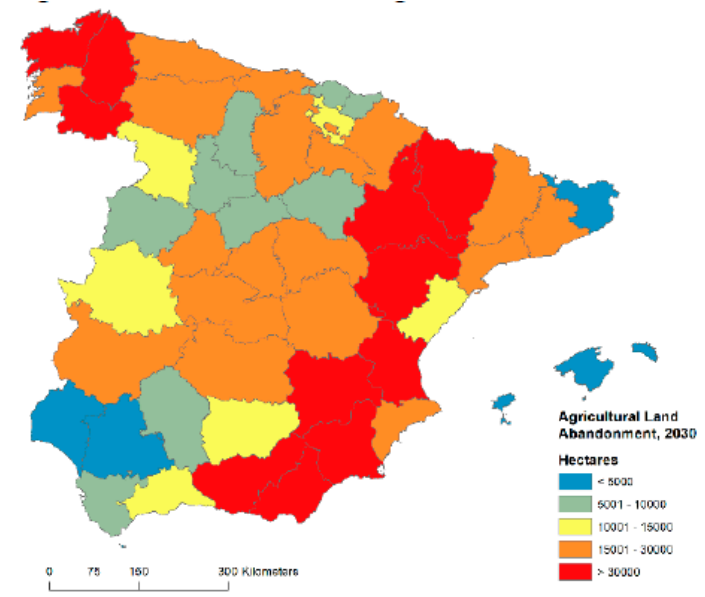

(a)

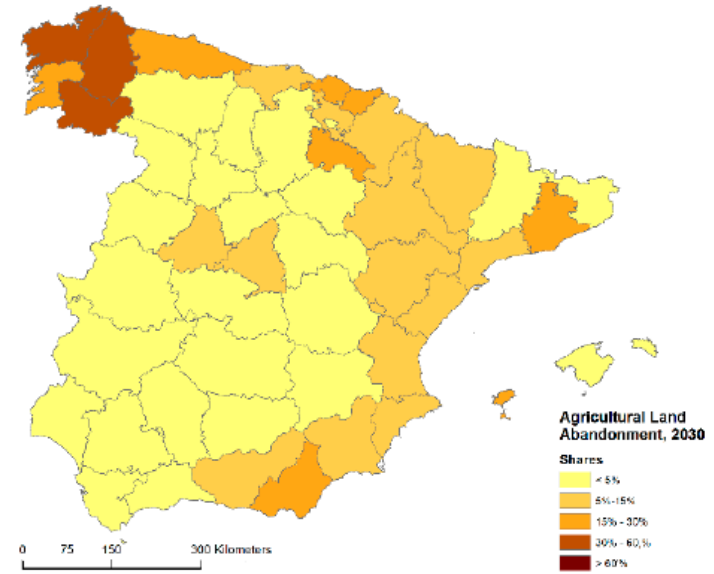

(b)

Figure 9. Agricultural land abandonment with regard to the total agricultural land aggregated at NUTS3 region level (provinces) in 2030. (a) Total hectares; (b) Shares.

\subsection{Agricultural Land Abandonment in Natural and Mountainous Areas}

As was mentioned in Section 2.3, totally mountain areas, high nature value farming areas and Natura 2000 sites are individually and spatially analysed in this section (Figure 10). In 2030, of all abandonment in Spain (roughly 1.1 million ha), almost half (505 Kha) will most likely occur in totally mountainous areas due to natural handicaps and difficult mechanisation, among other factors, which make those areas less competitive. Lugo, Ourense, Teruel, Granada and Almería are expected to undergo the highest abandonment extent (more than $25 \mathrm{Kha}$ ) due to the presence of important mountain ranges (Macizo Galaico, Iberian and Baetic mountain systems). In Spain, approximately 18 million ha are widely covered by HNV areas associated with low-intensity farming that integrates tradition livestock and orchards (olive, almonds, etc.) while keeping high levels of biodiversity and environmentally valuable habitats. Similar to what happened in mountainous areas, almost $45 \%$ of the projected abandonment (490 Kha) is located inside HNV farmland areas. Lugo is the only region with more than $25 \mathrm{Kha}$ of abandonment within those areas, followed by Zaragoza, Granada, Asturias, Teruel, Ourense, Valencia, Almería, Huesca and Ávila belong to the previous category (from 15 to $25 \mathrm{Kha}$ ). More conservative and protective vision seems to have the central (with the exception of Madrid and Ávila) and southwest 
of Spain, as well as Catalonia with regard to the EU Nature 2000 sites. In Spain, the Natura 2000 network is broadly distributed across the territory, accounting for almost 30\% (roughly 15 million ha). Abandonment inside Natura 2000 sites accounts for 152 Kha which represents about $14 \%$ of the total land abandonment. Granada, Valencia, Almería and Teruel are the provinces where agricultural land abandonment is taking place the most (greater than $7 \mathrm{Kha}$ ) corresponding to the highest category. This means that the conservation, maintenance and protection goals to support biodiversity within those areas are substantially effective compared to the abandonment outside.
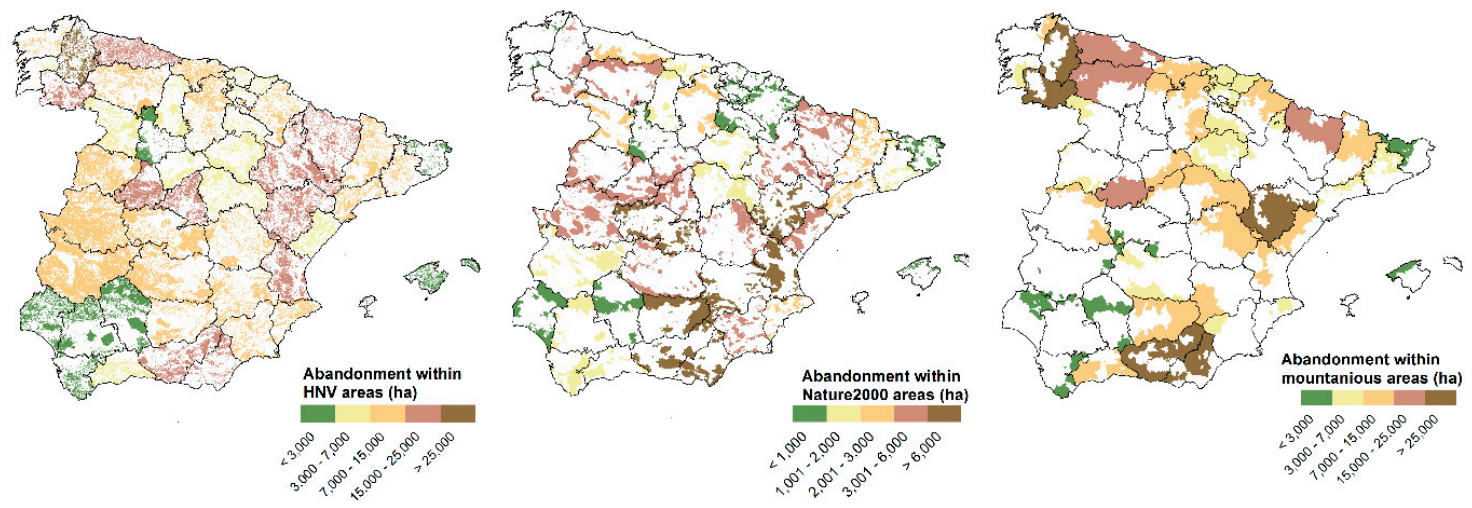

Figure 10. Agricultural abandonment on mountainous, high nature value and Natura 2000 areas per province (NUTS3 level) in 2030.

\subsection{Agricultural Land Abandonment at Local Scale (Spain)}

The modelling exercise allows us to analyse agriculture land abandonment at the local scale in Spain (Figure 11). Four zones are selected to exemplify areas affected by abandonment with different economic, environmental and regional contexts. In particular, Murcia, Toledo, Zaragoza and Lugo provinces (Figure 12) were chosen as representative zones of the eastern Mediterranean, the Central System, the Ebro Depression and the Galicia region, respectively, in which agricultural land abandonment is expected to be particularly prominent.

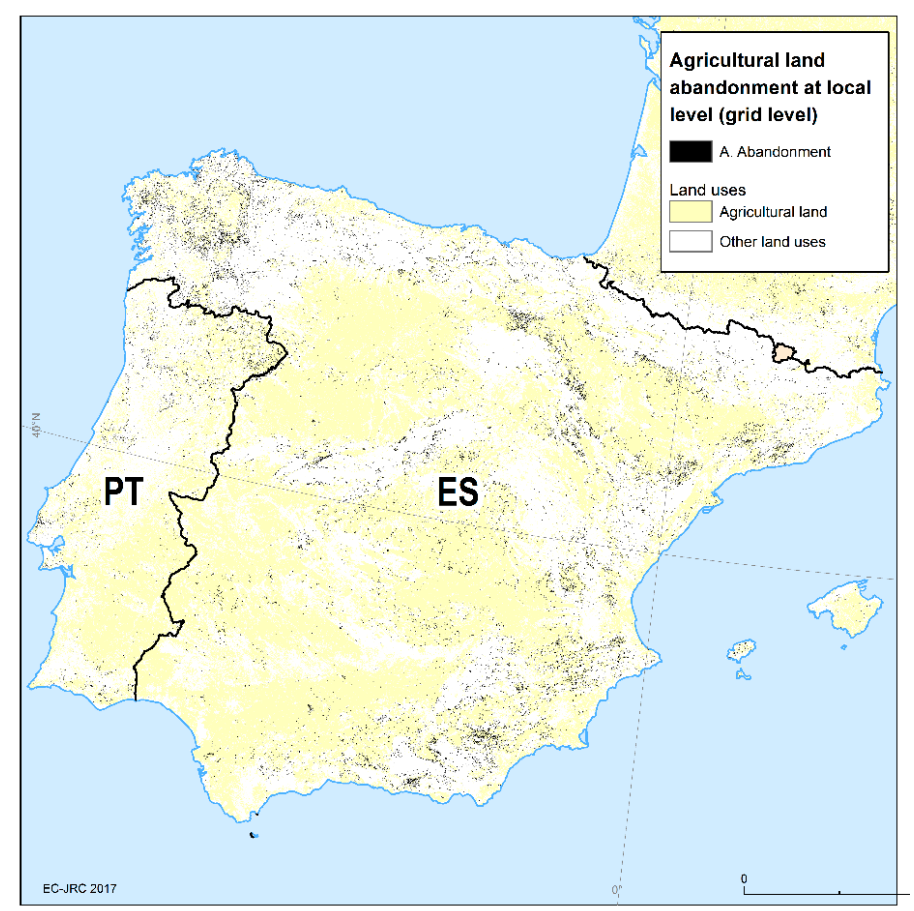

Figure 11. Agricultural land abandonment (black polygons) over the UAA at the grid level in 2030. 

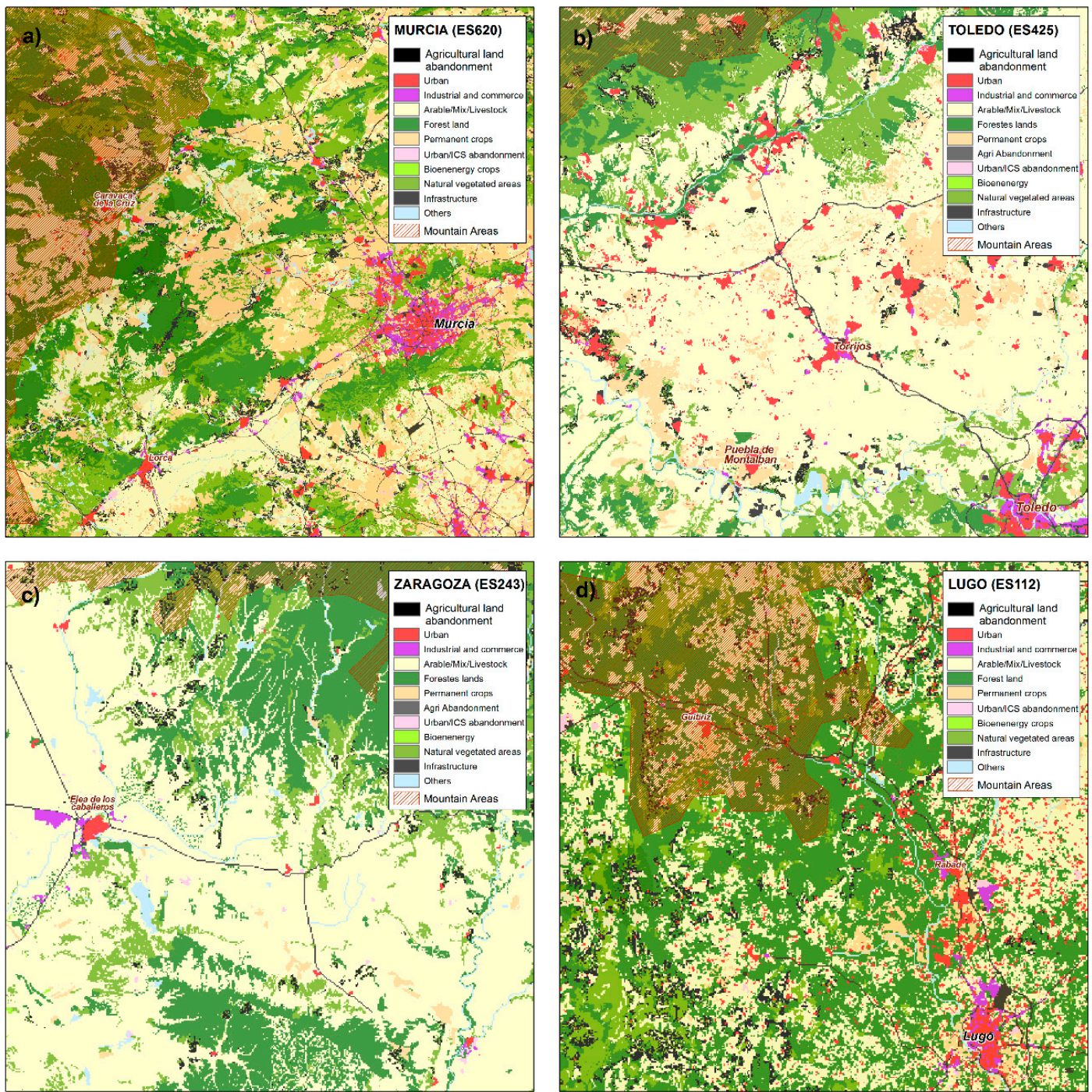

Figure 12. Visualization of four zooming areas (approximate scale 1:200,000) where black polygons represent abandonment land along with other land uses in 2030. (a) Murcia; (b) Toledo; (c) Zaragoza; (d) Lugo.

In the area located in the north-western part of Murcia city (Figure 12a), fruit trees are the dominant agricultural land. Permanent crop abandonment, thus, is the most common agricultural land affected by abandonment. However, arable land is also abandoned close to the urban centres (the cities of Cieza, Archen, Calasparra and Murcia) which might be related to urbanization processes (reserve of land around main cities). The selected area (in particular the western part) is also considered as a remote area. Besides, the area is classified as in danger of land-use abandonment and partially mountain areas according to the eligibility for less-favoured areas (LFA) due to natural constraints. The Murcia region is also characterized by high salinity concentration areas with the addition of low annual precipitation (dry area).

In the northern part of Toledo city (Figure 12b), agricultural land abandonment is mainly from arable land and patches of permanent crops, especially vineyards. This area is placed in the category of in danger of abandonment (as the risk map reflects), surrounded by mountain ranges, Sierra de Guadarrama (Sistema central) in the north and Montes de Toledo in the south, which characterises this area as moderately remote. Besides, there is an accumulation of at least three biophysical factors (slope higher than the range 15-30\%, heavy clay texture and annual precipitation below $400 \mathrm{~mm}$ ) which increase the risk abandonment. Furthermore, agriculture stability and viability for preventing 
farmland abandonment are considered very low only with moderate-income values at the regional level, likely influenced by the proximity to Madrid.

Figure 12c is located in the border between Zaragoza and Huesca provinces, close to Zaragoza city. It is an area with important geographic and topographic elements, such as the Ebro river catchment and the Sierra de Guara (Aragonese Pyrenees) on the northern side with a semi-arid Mediterranean climate. In the plain area predominates arable land, and land abandonment is mainly from this production system, especially within the dense forest and nature vegetated areas. Though it is also placed in a remote area surrounded by forest and steep terrain (near mountains), agroeconomic (including irrigation infrastructures) and favourable biophysical variables compensate for a massive abandonment. Natural constraints in this area can be considered modest and are related to some patches of salinity concentration, low root depth and low precipitation from the southern part of Zaragoza city.

The last zone (Figure 12d) covers the Lugo plateau surrounded by the Miño river, as well as a set of mountain ranges in the eastern part (Serras Orientais, Serra de Meira and Serra dos Ancares) and the Macizo Galaico in the west that defines the regional orography. The landscape intersperses highly diverse agricultural land together with leafy and abundant forest and naturally vegetated areas, mainly due to its humid oceanic climate. This geographical diversity entails the combination of different risk categories (low-moderate-high) of abandonment, being considered as an area totally in danger of abandonment. Moreover, there is an accumulation of biophysical factors spread in some places (slope higher than $15-30 \%$, low soil depth) which might increase locally the risk of abandonment. A low stability and viability for preventing farmland abandonment, according to the economic and structure farm variables, characterises this province.

\section{Discussion and Conclusion}

LUISA, as a spatial-explicit model conceived to contribute to territorial impact assessment and analysis of EU trends and policies, can help to understand to what extent, in time and space, agricultural land abandonment will affect in different regions in Spain. However, the LUISA model, as any other model simplifying the complex process in reality, entails limitations and uncertainties in the design and system (i.e., thematic, spatial and temporal resolution, data availability, geographical coverage, assumptions, scientific-based methods, etc.). One of the most important limitations in this study is the fact that the model configuration is implemented for the whole EU rather than for a particular Member State. This, specifically, means that using better spatial data, higher resolutions, country-specific assumptions/rules based on previous studies, regional/local statistics and so on, outcomes might considerably improve. However, this is not the main role of LUISA that serves to a more ambitious purpose in terms of thematic indicators (population, employment, industry, built-up areas, access to services, transportation, accessibility, etc.), coverage, new methods and techniques, impact assessment analysis, decision-making policy support and so on. It is worth mentioning, as another limitation cause, the selected driving factors (Table 1 and Figure 4) to build the EU risk map from European data sources. It is evident that the lack of higher resolution for some spatial layers (for instance, length growing period) and the low accuracy and spatial variability of some others (salinity, precipitation or sodicity factors) influence the quality of the final results. Besides this, a data harmonization process is necessarily applied to make consistent the inputs related to the agroeconomic and farm structural factors due mainly to missing regional data or discrepancies between NUTS3 versions $[57,58]$. Thus, even though LUISA results provide actual figures, the herein presented quantitative assessment needs to be cautiously interpreted owing to all mentioned aspects. However, as described below, LUISA spatially captures and identifies, in a faithful manner, the hotspot areas affected by agricultural abandonment at the local and regional scale.

During the last decade, different works and assessments have been considered as a benchmark from a European perspective $[6,7,10,12,16,64-68]$, though their methods, assumptions, nature of the work and results are considerably different. They have helped to explain and estimate to what extent land abandonment affects regions in terms of magnitude, location (spatial and temporal), but also, 
which are the driving forces and impacts. Many authors [13-17] demonstrated and highlighted the effects of agroecological, socioeconomic and farm structure variables in determining abandonment patterns which are fully in line with the set of driving factors used in the presented analysis. Recent studies also propose a broader list taking into account other variables like distance to the nearest forest, distance to farms, land consolidation, isolated agricultural plots within forest, proximity to markets, road density, landscape structure or irrigation maps among others $[8,14,20]$. Many of the mentioned works rely on spatially-explicit logistic regressions to assess the determinants of agricultural abandonment because they are relatively easy to understand and formulate [69]. Soil type, topography (elevation and slope) and rural population change were the most important variables explaining land abandonment in western Ukraine while infrastructure density, land-use intensity and distance were low significant contrarily to the initial hypothesis [25]. On the contrary, accessibility (distance to roads and to villages) was found an important driver of abandonment in the case of western European countries, age index and slope [67].

From European data sources, we firstly analyse and compare in this section the observed local abandoned rates from [6] (Appendix A) and the ones modelled from LUISA (Figure 11), especially the south-eastern part of Spain, Galicia, Pyrenees and the most inner and central part. Spain gathers the major number of case study areas mainly due to the large distribution of mountain ranges, from the north to the south, within the Iberian Peninsula. The spatially coinciding NUTS3 regions overlapping those observed abandonment hotspots are found in Cantabria, Asturias, Gipuzkoa, Madrid, Ávila, Salamanca, Lleida, Rioja, Zaragoza, Málaga, Granada and Almería. Thus, fifty-eight municipalities (Appendix B) captured by LUISA were analysed at the local level, in which abandonment shares ranging from $30 \%$ to $84 \%$, with the highest affected areas by abandonment in Lleida (El Pont de Suert, $84 \%$ ), north of Madrid (Navarredonda, San Mames and Puentes viejas, 80\%) and Zaragoza (Borja and Ainzon, $80 \%$ and $81 \%$, respectively). Secondly, based on remote-sensing observations, [15] predicted the likelihood of abandoned areas at the pan-European scale (European Union, Russia and Ukraine) using machine learning techniques based on a $5 \mathrm{~km}$ grid cell (pixel). Particularly, in the Iberian Peninsula, these predictions are not completely coincident with national studies carried out by many authors $[2,6,8,20,70,71]$ and also with LUISA outputs. North-western Spain (Galicia), south-eastern Spain (Murcia region) and northern Portugal are highly affected by abandonment; however, those regions were not captured by the predictions from that study.

After analysing and comparing local studies to LUISA outputs (Figures 9 and 11), this confirms that the biggest challenges in Spain are expected to take place, especially in its north-western part, where Lugo province will be affected the most by land abandonment in Galicia region. We reviewed the theoretical and qualitative work of $[27,28]$ centred on concepts, drivers and consequences of the abandonment of agriculture with a focus on Galicia. A more quantitative approach can be seen in $[8,27]$ using different statistical and cartographic data sources between 1956 and 2004, analysing the district of Terra Cha in Lugo Province. Variables such as slope and distance to farms were significantly correlated with high rates of abandonment while recovery for cultivation was related to accessibility, shape, slope and distance. The later article is contextualised on the IRENA Agri-Environmental Indicators (European Commission) where the indicator of "Risk of Farmland Abandonment" is calculated at the municipality level in Galicia. A response variable referred to as "abandoned.uaa" can be compared with what LUISA simulates. Particularly, a strong correlation can be seen between abandonment and slope, population density and travel time. In terms of location and extent in this study, we can find municipalities with abandonment shares over the total UAA ranging from $29.6-73 \%$, similarly to the LUISA model, especially in the central and south-eastern part of Lugo and Ourense (bordering on Asturias, Leon and Zamora regions). Another cluster of regions can be found in the inner part of Pontevedra limiting to the north of Ourense, while abandonment declines when approaches the coastline (Atlantic coast).

Other regions in the western Mediterranean basin, which are likely to face significant land abandonment, are located in Murcia, Málaga, Almería, Valencia and Alicante. [2] showed the prediction 
of a land abandonment map in Murcia using random forest techniques where the higher potential of abandonment appears in the northeast of the province (Yecla, Jumilla, Albanilla, Calasparra, Cieza, Fortuna, Albaran, etc.). LUISA also captures these hotspots ranging from $7 \%$ up to $20 \%$ of abandonment over the total UAA in the municipalities leading the ranking by 2030 if this trend continues over time. Guadalentin basin (southwest of Murcia limiting with Andalusia) is identified as an abandonment hotspot area by other authors [72,73] and also by the modelled LUISA results. The main difference compared to these studies is found in the Huerta y Campo de Murcia region (south-east of Murcia) where LUISA project less abandonment. Local studies in Valencia region (east Spain), Málaga and Almería regions (south-east Spain) has been carried out as representative Mediterranean areas prone to land abandonment, emphasizing the environmental impacts (soil erosion, increase in organic matter, infiltration capacity, vegetation recovery, etc.) when the phenomenon occurs $[18,19,21,29]$. The last Spanish regions with high potential of future abandonment according to LUISA are placed mainly in the Central Pyrenees, northern part of the Iberian Range and the inner side of the Ebro basin (Huesca, Navarra, La Rioja, Zaragoza and Teruel) whilst less pronounced in the Catalan Prelitoral (Lleida, Barcelona and Tarragona). During the last decades, many studies were focused on these areas at plot, catchment, local or regional scale, mainly dealing with the hydrological, geomorphological or land-use change effects of land abandonment rather than, in most cases, the abandonment of agricultural use per se $[20,29,74-79]$.

The lack of a homogeneous and continuous database or inventory of agricultural abandonment makes difficult further studies on this topic. As mentioned, most of the studies are local or regional, therefore, difficultly can be used for a straightforward comparison due to the usage of different territorial boundaries or the temporal component. The spatial data and statics currently used are not accurate enough for assessing farmland abandonment. Estimations based on remote sensing diverge from case studies due to the difficulties in land cover interpretation to distinguish between abandoned farmland and grazing area [80]. In Spain, some studies have used the SIOSE map for comparison and calibration of different model results $[2,73]$. Concerning statistical data $[8,10]$ stated that this complex and local phenomenon should be studied at a finer scale (LAU2, municipality level) rather than the usual NUTS3 level approach.

Agricultural land abandonment has been occurring over time and its expansion seems to continue happening not necessarily only in mountain and marginal areas but also in vulnerable regions. Spatial patterns of abandonment projected by the LUISA model have reflected a good spatial coincidence with the most affected areas observed in Spain which demonstrates that it can be a useful tool for case studies. LUISA, in the case of Spain, identifies a first group of regions located in the western Mediterranean belt (Valencia, Alicante, Murcia and Almería), Galicia region (Lugo, Ourense, Pontevedra and A Coruña), Central Pyrenees/Ebro Depression/North Iberian Range (Navarra, La Rioja, Huesca, Zaragoza, Teruel and Barcelona) where agricultural land abandonment is expected to be particularly prominent and, a second group in the Cantabrian mountains (Asturias and Cantabria) and the Central System (Madrid and Ávila). In summary, these findings indicate that agricultural abandonment is not equally spread across the country, ranging from less than $0.4 \%$ to more than $44 \%$ at the regional level (province) with an average greater than $10 \%$. Spain is expected to undergo an abandonment process that will reach roughly $5 \%$ (1.1 million ha) of the total agricultural land by 2030. Special attention must be paid to mountainous and natural protected areas (HNV farmland and Natura 2000 network) which cover an important proportion of its national area. Although LUISA does not integrate a specific artefact to directly prevent land abandonment within those policy-related layers, the results suggest that abandonment has a lower impact on them compared to outside places, likely due to the conservation measures to, among other purposes, prevent abandonment. The predicted abandonment in HNV and Natura 2000 areas to lead to a loss in farmland biodiversity and more intensive forms of agriculture.

Current work is focused on a validation exercise of the European risk map of agricultural land abandonment by means of regressions models. From a technical point of view, future work will improve the resolution (spatial and temporarily) of the main drivers and, in particular, remoteness areas 
(origin points) and the integration of irrigation maps. As we discussed in this article, agricultural land abandonment has a direct and indirect impact on the rural population and economy. An assessment of different socioeconomic and demographic factors in rural areas will take into account depopulation, ageing population, economic performance in the primary sector (employment, among other factors) and an attractiveness index in rural areas.

Author Contributions: C.P.C. conducted investigation, methodology of research and manuscript preparation. E.C.A. conducted formal and data analysis, visualization. C.L. conducted field research, project administration and supervision. J.C.M.L. conducted data preparation, manuscript preparation and correction. All authors have read and agreed to the published version of the manuscript.

Funding: This research received no external funding.

Conflicts of Interest: The authors declare no conflict of interest. The views expressed are purely those of the author and may not in any circumstances be regarded as stating an official position of the European Commission.

\section{Appendix A}

Abandonment observed hotspots numbered from 12 to 23 and from 31 to 35 [6] are located across the Cantabrian Mountain, Central System, Sistema Baetic, Iberian Range, Central Pyrenees and Catalan Prelitoral.

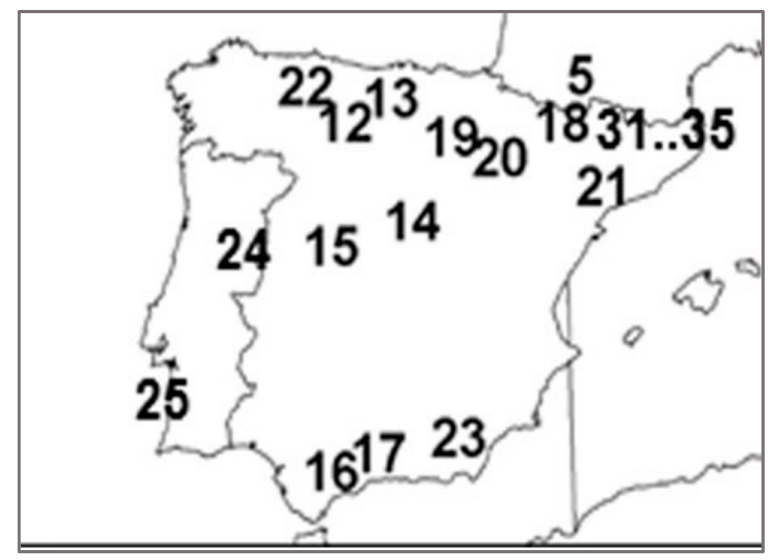

Figure A1. Farmland abandonment areas in Spain.

\section{Appendix B}

Table A1. Abandonment shares comparison between the observed and the modelled abandonment.

\begin{tabular}{|c|c|c|}
\hline $\begin{array}{c}\text { NUTS3 Region, } \\
\text { Abandonment Share }\end{array}$ & $\begin{array}{l}\text { Abandonment Areas from [6] } \\
\text { and Shares }\end{array}$ & Municipalities (LAU2) in LUISA and Shares \\
\hline Asturias (ES120), 15\% & $\begin{array}{l}\text { Abandonment areas numbered } \\
\text { as } 12,13 \text { and } 22 \text { with shares } \\
\text { between } 40 \% \text { and } 80 \%\end{array}$ & $\begin{array}{c}\text { Abandonment areas correspond to the municipalities of: Allande, } \\
\text { Teverga, Aller, Camaleño, Polaciones, Valdeolea and San Roque de } \\
\text { Riomiera ranging from } 38 \% \text { to } 53 \% \text { shares }\end{array}$ \\
\hline Madrid (ES300), 9\% & $\begin{array}{l}\text { Abandonment areas numbered } \\
\text { as } 14 \text { and } 15 \text { with shares } \\
\text { between } 75 \% \text { and } 89 \%\end{array}$ & $\begin{array}{c}\text { Abandonment areas correspond to the municipalities of: Puentes Viejas, } \\
\text { Navarredonda y San Mamés, Lozoyuela, Manzanares el Real, San } \\
\text { Ildefonso, Narrillos del Álamo, Orihuela, Medinilla, La Carrera and } \\
\text { Piedrahita ranging from } 42 \% \text { to } 81 \% \text { shares }\end{array}$ \\
\hline Lleida (ES513), 4.5\% & $\begin{array}{l}\text { Abandonment areas numbered } \\
\text { as } 18 \text { and } 21 \text { with shares } \\
\text { between } 40 \% \text { and } 71 \%\end{array}$ & $\begin{array}{c}\text { Abandonment areas correspond to the municipalities of: Torre de } \\
\text { Cabdella, Sort, Les Valls d'Aguilar, Prullans, La Vansa i Fórnols, El Pont } \\
\text { de Suert, Valderrobres, Monroyo, Castellote and Villarluengo ranging } \\
\text { from } 31 \% \text { to } 85 \% \text { shares }\end{array}$ \\
\hline Rioja (ES230), 17.5\% & $\begin{array}{l}\text { Abandonment areas numbered } \\
\text { as } 19 \text { and } 20 \text { with shares } \\
\text { between } 42 \% \text { and } 99 \%\end{array}$ & $\begin{array}{c}\text { Abandonment areas correspond to the municipalities of: San Asensio, } \\
\text { Cenicero, Sotés, Haro, Tarazona, Borja, Ainzón, Fuendejalón and } \\
\text { Morata de Jalón ranging from } 33 \% \text { to } 81 \% \text { shares }\end{array}$ \\
\hline Málaga (ES617), 10\% & $\begin{array}{l}\text { Abandonment area numbered } \\
\text { as } 16 \text { and } 23 \text { with shares } \\
\text { between } 36 \% \text { and } 70 \%\end{array}$ & $\begin{array}{c}\text { Abandonment areas correspond to the municipalities of: Villaluenga } \\
\text { del Rosario, Ronda, Alpujarra de la Sierra, Nevada, Albondón, } \\
\text { Torvizcón, Fiñana, Fondón, Felix, Lubrín, Macael, Oria and Chirivel } \\
\text { ranging from } 45 \% \text { to } 74 \% \text { shares }\end{array}$ \\
\hline
\end{tabular}




\section{References}

1. Gellrich, M.; Zimmermann, N.E. Investigating the regional-scale pattern of agricultural land abandonment in the Swiss mountains: A spatial statistical modelling approach. Landsc. Urban Plan. 2007, 79, 65-76. [CrossRef]

2. Alonso-Sarría, F.; Martínez-Hernández, C.; Romero-Díaz, A.; Cánovas-García, F.; Gomariz-Castillo, F. Main environmental features leading to recent land abandonment in Murcia region (southeast Spain). Land Degrad. Dev. 2016, 27, 654-670. [CrossRef]

3. Falcucci, A.; Maiorano, L.; Boitani, L. Changes in land-use/land-cover patterns in Italy and their implications for biodiversity conservation. Landsc. Ecol. 2007, 22, 617-631. [CrossRef]

4. Poyatos, R.; Latron, J.; Llorens, P. Land use and land cover change after agricultural abandonment. Mt. Res. Dev. 2003, 23, 362-368. [CrossRef]

5. Etienne, M.; Le Page, C.; Cohen, M. A Step-By-Step Approach to Building Land Management Scenarios Based on Multiple Viewpoints on Multi-Agent System Simulations Ecology and Society. Available online: http://jasss.soc.surrey.ac.uk/6/2/2.html (accessed on 10 March 2019).

6. Lasanta. T.; Arnáez, J.; Pascual, N.; Ruiz-Flañ0, R.; Errea, M.P.; Lana-Renault, N. Space-time process and drivers of land abandonment in Europe. Catena 2016, 149, 810-823.

7. MacDonald, D.; Crabtree, J.R.; Wiesinger, G.; Dax, T.; Stamou, N.; Fleury, P.; Gutierrez Lazpita, J.; Gibon, A. Agricultural abandonment in mountain areas of Europe Environmental consequences end policy response. J. Environ. Manag. 2000, 59, 47-69. [CrossRef]

8. Corbelle-Rico, E.; Crecente-Maseda, R.; Santé-Riveira, I. Multi-scale assessment and spatial modelling of agricultural land abandonment in a European peripheral region: Galicia (Spain), 1956-2004. Land Use Policy 2012, 29, 493-501. [CrossRef]

9. Leal Filho, W.; Mandel, M.; Al-Amin, A.Q.; Feher, A.; Chiappetta Jabbour, C.J. An assessment of the causes and consequences of agricultural land abandonment in Europe. Int. J. Sustain. Dev. World Ecol. 2016, 24, 554-560. [CrossRef]

10. Pointereau, P.; Coulon, F.; Girard, P.; Lambotte, M.; Stuczynski, T.; Sanchez Ortega, V.; Del Rio, A. Analysis of Farmland Abandonment and the Extent and Location of Agricultural Areas that Are Actually Abandoned or Are in Risk to Be Abandoned; Publications Office of the European Union: Luxembourg, 2008; JRC46185; ISSN 1018-5593.

11. Van Leeuwen, C.C.E.; Cammeraat, E.L.H.; de Vente, J.; Boix-Fayos, C. The evolution of soil conservation policies targeting land abandonment and soil erosion in spain: A review. Land Use Policy 2019, 83, 174-186. [CrossRef]

12. Benayas, J.M.; Martins, A.; Nicolau, J.M.; Schulz, J.J. Abandonment of agricultural land: An overview of drivers and consequences. CAB Rev. Perspect. Agric. Vet. Sci. Nutr. Nat. Resour. 2007, 2, 1-14. [CrossRef]

13. Terres, J.M.; Nisini Scacchiafichi, L.; Wania, A.; Ambar, M.; Anguiano, E.; Buckwell, A.; Coppola, A.; Gocht, A.; Nordström Källström, A.; Pointereau, P.; et al. Farmland abandonment in Europe: Identification of drivers and indicators, and development of a composite indicator of risk. Land Use Policy 2015, 49, 20-34. [CrossRef]

14. Prishchepov, A.V.; Müller, D.; Dubinin, M.; Baumann, M.; Radeloff, V.C. Determinants of agricultural land abandonment in post-Soviet European Russia. Land Use Policy 2013, 30, 873-884. [CrossRef]

15. Levers, C.; Schneider, M.; Prishchepov, A.V.; Estel, S.; Kuemmerle, T. Spatial variation in determinants of agricultural land abandonment in Europe. Sci. Total. Environ. 2018, 644, 95-111. [CrossRef] [PubMed]

16. Keenleyside, C.; Tucker, G.M. Farmland Abandonment in the EU: An Assessment of Trends and Prospects; Report prepared for WWF; Institute for European Environmental Policy: Bruxelles, Belgium, 2010.

17. Lasanta, T.; Vicente-Serrano, S.M.; Cuadrat, J.M. Mountain Mediterranean landscape evolution caused by abandonment of traditional primary activities: A study of the Spanish Central Pyrenees. Appl. Geogr. 2005, 25, 47-65. [CrossRef]

18. Rodrigo-Comino, J.; Martínez-Hernández, C.; Iserloh, T.; Cerdà, A. Contrasted impact of land abandonment on soil erosion in Mediterranean agriculture fields. Pedosphere 2018, 28, 617-631. [CrossRef]

19. Cerdà, A.; Rodrigo-Comino, J.; Novara, A.; Brevik, E.C.; Vaez, R.V.; Pulido, M.; Giménez-Morera, A.; Keesstra, S.D. Long-term impact of rainfed agricultural land abandonment on soil erosion in the Western Mediterranean basin. Prog. Phys. Geogr. 2018, 42, 202-219.

20. Lasanta, T.; Errea, M.P.; Ortigosa, L. Land abandonment, landscape evolution, and soil erosion in a Spanish Mediterranean mountain region: The case of Camero Viejo. Land Degrad. Dev. 2011, 22, 537-550. 
21. Romero-Díaz, A.; Ruiz-Sinoga, J.D.; Robledano-Aymerich, F.; Brevik, E.C.; Cerdà, A. Ecosystem responses to land abandonment in Western Mediterranean Mountains. Catena 2017, 149, 824-835. [CrossRef]

22. Land Abandonment, Biodiversity and the CAP. In Proceedings of the Outcomes of an International Seminar, Sigulda, Latvia, 7-8 October 2004.

23. Elbersen, B.; Beaufoy, G.; Jones, G.; Noij, G.-J.; Doorn, A.; Breman, B.; Hazeu, G. Aspects of data on diverse relationships between agriculture and the environment. In Report for DG-Environment; Alterra: Wageningen, The Netherlands, 2014.

24. ECORYS. SEGIRA-Study on employment, growth and innovation in rural areas. In Main Report; ECORYS: Rotterdam, The Netherlands, 2010.

25. Baumann, M.; Kuemmerle, T.; Elbakidzed, M.; Ozdogan, M.; Radeloff, V.; . Keuler, N.; Prishchepov, A.; Kruhlov, I.; Hostert, P. Patterns and drivers of post-socialist farmland abandonment in Western Ukraine. Land Use Policy 2011, 28, 552-562. [CrossRef]

26. Pazúr, R.; Lieskovský, J.; Feranec, J.; Otahel, J. Spatial determinants of abandonment of large-scale arable lands and managed grasslands in Slovakia during the periods of post-socialist transition and European Union accession. Appl. Geogr. 2014, 54, 118-128. [CrossRef]

27. Corbelle-Rico, E.; Crecente-Maseda, R. Evaluating IRENA indicator "Risk of Farmland Abandonment" on a low spatial scale level: The case of Galicia (Spain). Land Use Policy 2014, 38, 9-15. [CrossRef]

28. Corbelle-Rico, E.; Crecente-Maseda, R. Land abandonment: Concept and consequences. Revista Galega de Economía 2008, 17, 2-15.

29. García-Ruiz, J.M. The effects of land uses on soil erosion in Spain: A review. Catena 2010, 81, 1-11. [CrossRef]

30. Eurostat (2016)_EUROPOP2013, Convergence Scenario, National Level. Available online: http://epp. eurostat.ec.europa.eu/cache/ITY_SDDS/EN/proj_10c_esms.htm (accessed on 15 January 2016).

31. Britz, W.; Witzke, H.P. CAPRI Model Documentation 2012. Institute for Food and Resource Economics; University Bonn: Bonn, Germany, 2012.

32. European Commission. General Equilibrium Model for the Economy-Energy-Environment (GEM-E3). Available online: https://ec.europa.eu/jrc/en/gem-e3/model (accessed on 15 November 2018).

33. European Commission-Joint Research Centre. Dynamic Spatial General Equilibrium Model for EU Regions and Sectors (RHOMOLO). Available online: https://ec.europa.eu/jrc/en/rhomolo (accessed on 8 February 2018).

34. European Commission-Joint Research Centre. JRC-EU-Times Model Assessing Long Term Role Energy Technologies. Available online: https://ec.europa.eu/jrc/en/scientific-tool/jrc-eu-times-model-assessing-longterm-role-energy-technologies (accessed on 25 January 2016).

35. Baranzelli, C.; Jacobs-Crisioni, C.; Batista e Silva, F.; Perpiña Castillo, C.; Barbosa, A.; Arevalo Torres, J.; Lavalle, C. The reference scenario in the LUISA platform-Updated configuration 2014 towards a common baseline scenario for EC impact assessment procedures. Publ. Off. Eur. Union Luxemb. 2014, 10, 85104.

36. Jacobs-Crisioni, C.; Diogo, V.; Perpiña Castillo, C.; Baranzelli, C.; Batista e Silva, F.; Rosina, K.; Kavalov, B.; Lavalle, C. The LUISA Territorial Reference Scenario: A Technical Description; Publications Office of the European Union: Luxembourg, 2017. [CrossRef]

37. Batista e Silva, F.; Lavalle, C.; Koomen, E. A procedure to obtain a refined European land use/cover map. J. Land Use Sci. 2013, 8, 255-283. [CrossRef]

38. McFadden, D. Modeling the Choice of Residential Location. Transp. Res. Rec. 1978, 672, $72-77$.

39. Hilferink, M.; Rietveld, P. Land use scanner: An integrated GIS based model for long term projections of land use in urban and rural areas. J. Geogr. Syst. 1999, 1, 155-177.

40. Koomen, E.; Diogo, V.; Dekkers, J.; Rietveld, P. A utility-based suitability framework for integrated local-scale land-use modelling. Comput. Environ. Urban Syst. 2015, 50, 1-14. [CrossRef]

41. Perpiña Castillo, C.; Kavalov, B.; Ribeiro Barranco, R.; Diogo, V.; Jacobs-Crisioni, C.; Batista e Silva, F.; Baranzelli, C.; Lavalle, C. Territorial Facts and Trends in the EU Rural Areas within 2015-2030; Publications Office of the European Union: Luxembourg, 2018; JRC114016; ISBN 978-92-79-98121-0. [CrossRef]

42. Lavalle, C.; Pontarollo, N.; Batista, E.; Silva, F.; Baranzelli, C.; Jacobs, C.; Kavalov, B.; Kompil, M.; Perpiña Castillo, C.; Vizcaino, M.; et al. European Territorial Trends_Facts and Prospects for Cities and Regions; Publications Office of the European Union: Luxembourg, 2017; JRC107391; ISBN 978-92-79-73428-1. [CrossRef]

43. Perpiña Castillo, C.; Lavalle, C.; Baranzelli, C.; Mubareka, S. Modelling the spatial allocation of secondgeneration feedstock (lignocellulosic crops) in Europe. International J. Geogr. Inf. Sci. 2015, 29, 1807-1825. [CrossRef] 
44. Kompil, M.; Jacobs-Crisioni, C.; Dijkstra, L.; Lavalle, C. Mapping access to generic services in Europe: A market-potential based approach. Sustain. Cities Soc. 2019, 4, 101372. [CrossRef]

45. Jacobs-Crisioni, C.; Batista e Silva, F.; Lavalle, C.; Baranzelli, C.; Barbosa, A.; Perpiña Castillo, C. Accessibility and territorial cohesion in a case of transport infrastructure improvements with changing population distributions. Eur. Transp. Res. Rev. 2016, 8, 9. [CrossRef]

46. European Commission-Joint Research Centre. Available online: https://urban.jrc.ec.europa.eu/\#/en (accessed on 10 December 2019).

47. European Commission-Joint Research Centre. Available online: https://ec.europa.eu/knowledge4policy/ online-resource/territorial-dashboard_en (accessed on 10 December 2019).

48. European Commission, Eurostat. Available online: http://ec.europa.eu/eurostat/web/gisco/geodata/referencedata/administrative-units-statistical-units/nuts (accessed on 10 December 2019).

49. European Commission-Joint Research Centre. LUISA Collection, Data Catalogue. Available online: https://data.jrc.ec.europa.eu/collection/luisa (accessed on 10 December 2019).

50. European Commission-Joint Research Centre. LUISA Territorial Modelling Platform. Available online: https://ec.europa.eu/jrc/en/luisa (accessed on 10 December 2019).

51. IIASA/FAO. Global Agro-Ecological Zones_GAEZ Portal. 2013. Available online: http://www.gaez.iiasa.ac. at/ (accessed on 7 April 2017).

52. Hiederer, R. Processing a Soil Organic Carbon C-Stock Baseline under Cropland and Grazing Land Management. In EUR 28158 EN; Publications Office of the European Union: Luxembourg, 2016. [CrossRef]

53. FAO/IIASA/ISRIC/ISSCAS/JRC. Harmonized World Soil Database (Version 1.2); FAO: Rome, Italy; IIASA: Laxenburg, Austria, 2012.

54. European Commission-Joint Research Centre; European Soil data Centre (ESDAC); Sinfo (Soil data for the MARS). Data for the Soil Information System for the MARS Crop Yield Forecasting System (SINFO). Available online: https://esdac.jrc.ec.europa.eu/sinfo-soil-data-mars-information (accessed on 20 May 2017).

55. European Commission-Joint Research Centre; European Soil data Centre (ESDAC); European Food Safety Authority (EFSA). Spatial Data Version 1.1. Available online: https://esdac.jrc.ec.europa.eu/content/europeanfood-safety-authority-efsa-data-persam-software-tool (accessed on 5 July 2017).

56. NASA (National Aeronautics and Space Administration). Shuttle Radar Topography Mission (SRTM). Available online: http://www2.jpl.nasa.gov/srtm/ (accessed on 20 September 2018).

57. European Commission, Eurostat. Farm structure surveys (FSS)-Structure of agricultural holdings. Available online: https://ec.europa.eu/eurostat/statistics-explained/index.php?title=Main_Page (accessed on 15 March 2018).

58. European Commission, Farm Accountancy Data Network (FADN). Special request of microdata to DG Agriculture and rural Development, Farm Economics Unit. Available online: http://ec.europa.eu/agriculture/ rica/ (accessed on 15 March 2018).

59. Dijkstra, L.; Poelman, H. A Harmonised Definition of Cities and Rural Areas: The New Degree of Urbanisation; Regional Policy Working Papers; European Commission, Directorate-General for Regional and Urban Policy: Brussels, Belgium, 2014.

60. Eliasson, Å.; Jones, R.J.; Nachtergaele, F.; Rossiter, D.G.; Terres, J.M.; Van Orshoven, J.; Van Velthuizen, H.; Böttcher, K.; Haastrup, P.; Le Bas, C. Common criteria for the redefinition of intermediate less favoured areas in the European Union. Environ. Sci. Policy 2010, 13, 766-777. [CrossRef]

61. Council Directive 95/212/EC of 29 May 1995 concerning the Community list of less-favoured farming areas within the meaning of Directive 75/268/EEC.

62. EEA-European Environment Agency. High Nature Value (HNV) Farmland. European Environment Agency, Copenhagen, Denmark. 2015. Available online: http://www.eea.europa.eu/data-and-maps/data/ high-nature-value-farmland (accessed on 23 June 2019).

63. EEA-European Environment Agency. Natura 2000 Data-the European Network of Protected Sites. European Environment Agency, Copenhagen, Denmark. 2017. Available online: http://www.eea.europa.eu/ data-and-maps/data/natura-8 (accessed on 23 June 2019).

64. Walford, N. Agricultural adjustment: Adoption of an adaptation to policy reform by large-scale commercial farmers. Land Use Policy 2002, 19, 243-257. [CrossRef]

65. Renwick, A.; Jansson, T.; Verburg, P.H.; Revoredo-Giha, C.; Britz, W.; Gocht, A.; McCracken, D. Policy reform and agricultural land abandonment in the EU. Land Use Policy 2013, 30, 446-457. [CrossRef] 
66. Bakker, M.M.; Govers, G.; van Doorn, A.; Quetier, F.; Chouvardas, D.; Rounsevell, M. The response of soil erosion and sediment export to land-use change in four areas of Europe: The importance of landscape pattern. Geomorphology 2008, 98, 213-226.

67. Nowicki, P.L.; Van Meijl, H.; Kneirim, A.; Banse, M.A.; Belling, M.; Helming, J.F.; Leibert, T.; Lentz, S.; Margraf, O.; Matzdorf, B.; et al. SCENAR 2020. Scenario Study on Agriculture and the Rural World; European Commission, Directorate-General Agriculture and Rural Development and Directorate, G. Economic analysis and evaluation. Contract No. 30-CE-0040087/00-08; Office for Official Publications of the European Communities: Luxembourg, 2007; ISBN 978-92-79-05441-9.

68. Westhoek, H.J.; Van den Berg, M.; Bakkes, J.A. Scenario development to explore the future of Europe's rural areas. Agric. Ecosyst. Environ. 2006, 114, 7-20. [CrossRef]

69. Müller, D.; Leitão, P.; Sikor, T. Comparing the determinants of cropland abandonment in Albania and Romania using boosted regression trees. Agric. Syst. 2013, 117, 66-77. [CrossRef]

70. Pinto Correia, T. Threatned landscape in Alentejo, Portugal: The "montado" and other "agro-silvo pastoral systems". Landsc. Urban Plan. 1993, 24, 43-48. [CrossRef]

71. Nunes, A.N.; de Almeida, A.C.; Coelho, C.O.A. Impact of land use and cover type on runoff and erosion in a marginal area of Portugal. Appl. Geogr. 2011, 31, 687-699. [CrossRef]

72. Calatrava, J.; Barbera, G.G.; Castillo, V.M. Farming practices and policy measures for agricultural soil conservation in semi-arid mediterranean areas: The case of Guadalentin basin in southeast Spain. Land Degrad. Dev. 2011, 22, 58-69. [CrossRef]

73. Martínez-Hernández, C.; Cánovas-García, F.; Alonso-Sarria, F.; Romero-Díaz, A.; Belmonte-Serrato, F. Cartografía de áreas agrícolas abandonadas mediante técnicas de SIG y fotointerpretación. In Comarcas de la Huerta y Campo de Murcia y Alto Guadalentín; Universidad de Murcia, Departamento de Geografía: Murcia, Spain, 2010.

74. Nadal-Romero, E.; Cammeraat, E.; Pérez-Cardiel, E.; Lasanta, T. Effects of secondary succession and afforestation practices on soil properties after cropland abandonment in humid Mediterranean mountain areas. Agric. Ecosyst. Environ. 2016, 228, 91-100. [CrossRef]

75. Maiso, E.; Lasanta, T. El espacio agrario en el valle del Linares: Características y utilización reciente. Berceo 1990, 118, 53-62.

76. Sanjuán, Y.; Arnáez, J.; Beguería, S.; Lana-Renault, N.; Lasanta, T.; Gómez-Villar, A.; Álvarez-Martínez, J.; Coba-Pérez, P.; García-Ruiz, J.M. Woody plant encroachment following grazing abandonment in the subalpine belt: A case study in northern Spain. Reg. Environ. Chang. 2018, 18, 1003-1115. [CrossRef]

77. Sauer, T.; Ries, J. Vegetation cover and geomorphodynamics on abandoned fields in the Central Ebro Basin (Spain). Geomorphology 2008, 102, 267-277. [CrossRef]

78. Vila Subirós, J.; Rodríguez-Carreras, R.; Varga, D.; Ribas, A.; Úbeda, X.; Asperó, F.; Llausàs, A.; Outeiro, L. Stakeholders perceptions of landscape changes in the Mediterranean mountains of the North-Eastern Iberian Peninsula. Land Degrad. Dev. 2015. [CrossRef]

79. Badía, A.; Pélachs, A.; Vera, A.; Tulla, A.F.; Soriano, J.M. Cambios en los usos del suelo y cubiertas del suelo y los efectos en la vulnerabilidad en las comarcas de montaña de Cataluña. Del rol del fuego como herramienta de gestión a los incendios como amenaza. Pirineos 2014, 169. [CrossRef]

80. Verburg, P.H.; Overmars, K. Combining top-down and bottom-up dynamics in land use modeling: Exploring the future of abandoned farmlands in Europe with the Dyna-CLUE model. Landsc. Ecol. 2009, 24, 1167-1181. [CrossRef]

(C) 2020 by the authors. Licensee MDPI, Basel, Switzerland. This article is an open access article distributed under the terms and conditions of the Creative Commons Attribution (CC BY) license (http://creativecommons.org/licenses/by/4.0/). 